\title{
THE HISTORY OF BIOCHEMISTRY
}

УДК 001.895:615

doi: https://doi.org/10.15407/ubj90.01.077

\section{ІННОВАЦІЙНА ДІЯЛЬНІСТЬ ІНСТИТУТУ БІОХІМІЇ \\ ІМ. О. В. ПАЛЛАДІНА НАН УКРАЇНИ: ПРОБЛЕМИ І ПЕРСПЕКТИВИ}

\author{
Г. Г. ЛУГОВСЬКА, В. М. ДАНИЛОВА, С. В. КОМІСАРЕНКО
}

Інститут біохімії ім. О. В. Палладіна НАН України, Київ; e-mail:valdan@biochem.kiev.ua

\begin{abstract}
Проведено історико-наукознавчий аналіз досягнень науковиів Інституту біохімії ім. О. В. Палладіна НАН України у винахідницькій діяльності для потреб медицини, сільського господарства, екологї, промисловості. Проаналізовано об'єкти права інтелектуальної власності Інституту; описано перспективні інноваційні розробки. На основі проведеного аналізу зроблено висновок, щзо винахідницька діяльність науковихустанов, зокрема Інституту біохімії ім. О. В. Палладіна НАН України, та впровадження наукових розробок, новітніх технологій у виробництво може забезпечити як підприємствам, так і країні в изілому економічне зростання та економію ресурсів, щзо є особливо важливим в умовах ринку.
\end{abstract}

Ключов і слова: інноваційна діяльність, винахідницка діяльність, інтелектуальна власність, авторське свідоцтво, патент, імуноензиматичні тест-системи, вітамінні комплекси.

3 а понад 90 років своєї історії Інститут біохімії ім. О.В. Палладіна НАН України (ІБХ) зробив значний внесок у скарбницю досягнень світової біохімічної науки. Національним надбанням стали доробки наукових шкіл видатних учених, фундаторів основних напрямів біохімії, молекулярної і клітинної біології та біотехнології, членів академії наук України: О. В. Палладіна, Р. В. Чаговця, М. Ф. Гулого, Д. Л. Фердмана, В. О. Бєліцера, С. В. Комісаренка, професорів В. П. Вендта, О. С. Циперовича, В. П. Короткоручка, С. О. Кудінова та багатьох інших.

Науковці Інституту завжди прагнули втілювати фундаментальні здобутки й теоретичні досягнення у практичні розробки. Аналіз винахідницької діяльності Інституту за весь період його існування був проведений нами i досить детально описаний в статтях, опублікованих в Ukrainian Biochemical Journal за 2015-2017 роки, починаючи 3 короткого огляду [1]. Виходячи з викладеного в цих публікаціях аналізу, можна з впевненістю стверджувати, що загалом внесок учених ІБХ у медичну практику і народне господарство країни надзвичайно вагомий. Ними одержано низку принципово нових результатів, які сприяють створенню нових біотехнологій одержання лікарських засобів, способів хімічної модифікації біологічно активних речовин, розробці тест-систем для вдосконалення діагностики і лікування різних захворювань.

Аби впевнитися в цьому, досить навести кілька яскравих прикладів практичного впровадження наукових розробок ІБХ від початку його створення і до 90-х років.

Так, пропагуючи досягнення біохімії серед медичних працівників і широких верств насе-

(C) 2017 Lugovska G. G. et al. This is an open-access article distributed under the terms of the Creative Commons Attribution License, which permits unrestricted use, distribution, and reproduction in any medium, provided the original author and source are credited. 
лення О. В. Палладін вже в 30-ті роки XX ст. заклав наукові основи раціонального харчування. А під час другої світової війни під його керівництвом було розроблено технологію одержання водорозчинного препарату вітаміну К вікасолу [2], який знайшов широке застосування у шпиталях, а згодом і в цивільній медичній практиці як кровоспинний засіб.

У 50-ті роки XX ст. під керівництвом акад. В. О. Бєліцера було розроблено методі технологію виробництва протеїнового кровозамінника БК-8 [3] для парентерального протеїнового харчування у разі виснаження, шоку, опіків, великих втрат крові, гнійно-запальних процесів, перитоніту, кишкової непрохідності. Під керівництвом д.б.н., проф. О. С. Циперовича було розроблено нові технологічні схеми виробництва препаратів «Медичний пепсин», «Шлунковий сік», «Пепсин високоактивний», які було впроваджено на багатьох виробництвах СРСР $[4,5]$. Крім того, співробітниками Інституту біохімії було створено нові технології виробництва таких медичних препаратів, як «Кристалічний трипсин», впроваджений на заводі біохімічних препаратів у м. Олайне (Латвія); «Хімотрипсин високоочищений», «Трипсин високоочищений», «Амілаза медична», на які був одержаний дозвіл Фармакологічного комітету МОЗ СРСР для клінічного випробування, що 3 позитивними результатами було проведено в медичних установах різних міст. Зараз вже доведено, що ензиматичні препарати $\epsilon$ високоефективними лікарськими засобами.

В ті ж самі роки під керівництвом чл.-кор. АН СРСР і УРСР Д. Л. Фердмана було розроблено препарат «3\%-й розчин монокальцієвої солі АТP у гліцерині» [6] для лікування прогресуючої м'язової дистрофії, поліомієліту і церебральних спазматичних паралічів, який було запроваджено на Дарницькому хімікофармацевтичному заводі. Проф. М. Д. Курський разом зі співробітниками кафедри акушерства і гінекології Київського медичного інституту iм. О. О. Богомольця під керівництвом проф. М. С. Бакшеєва розробили метод збудження i підсилення скоротливої здатності м'язів матки медіатором серотоніном, який було впроваджено в акушерську практику.

Важливими для медицини також були роботи з біохімії похідних стеринів і вітаміну D, проведені під керівництвом д.б.н., проф.
В. П. Вендта. Ним розроблено технологію промислового виробництва вітчизняного препарату вітаміну $\mathbf{D}_{3}[7,8]$, яку було впроваджено на Київському вітамінному заводі (1954-1955рр.), а також вітамінних заводах Сревану і Ленінграда (тепер - С.-Петербург). Пізніше він одержав комплекс медичного препарату вітаміну $\mathrm{D}_{3} 3$ казеїном, який отримав назву «Відеїн 3» [9], що використовувався 3 метою профілактики і лікування рахіту в дітей і вироблявся на тому самому заводі в Києві. У 1997 р. за результатами Всеукраїнської виставки-конкурсу лікувальних засобів та продуктів харчування, що сприяють виведенню радіонуклідів 3 організму людини та iï оздоровленню, препарат «ВІДЕЇН 3» виробництва Київського вітамінного заводу було визнано кращим в Україні та нагороджено Знаком благодійства за високу якість та технологічні досягнення 3 врученням диплому міжнародної асоціації «Допомога родинам Чорнобиля». За висновками міжнародної експертизи програми TACIS, виконаної для ЗАT «Київський вітамінний завод» у 2006 р., «ВІДЕЇН 3» визнано унікальним препаратом порівняно з іншими препаратами на ринку, що містять вітамін $\mathrm{D}_{3}$. Препарат «ВІДЕЇН 3» не має аналогів у Східній та Центральній Європі [9].

В. П. Вендт запропонував і впровадив у медичну практику метод ранньої діагностики D-гіповітамінозу в дітей молодшого віку i метод визначення ступеня ризику захворювання на рахіт немовлят на основі даних аналізу пуповинної крові. Вперше в нашій країні В. П. Вендт і Р. І. Яхимович одержали кристалічний вітамін $\mathrm{D}_{3}$ i його комплекс із холестеролом, названий ними «Відехол» [10]. Він вироблявся на хіміко-фармацевтичному об’єднанні «Дарниця» і успішно застосовувався для профілактики і лікування рахіту в дітей. «Відехол» і досі виробляється на ЗАТ НПК «Эоџ (РФ).

Академік М. Ф. Гулий, сповідуючи життєве i наукове кредо «Біохімія на користь людству», вважав, що «справжні фундаментальні дослідження, як правило, рано чи пізно приведуть до вирішення тих чи інших практичних завдань, які ставить перед людством житmя». Саме тому практичні здобутки наукової роботи М. Ф. Гулого виявилися такими ж вагомими, масштабними та різноманітними, як i наукові. Так, дослідження ролі вуглекисло- 
ти в організмі тварин дало практичні результати: М. Ф. Гулий зі співробітниками відділу регуляції обміну речовин створили препарати «Карбоксилін» та декілька його модифікацій (МП-15 та МП-30) - мінеральні амонійні препарати, які значно підвищували продуктивність сільськогосподарських тварин і птиці. Оскільки препарат був недорогим, доступним і достатньо ефективним (10 карбованців прибутку на 1 карбованець витрат), почалося широке будівництво підприємств 3 виробництва i впровадження у тваринництво препарату «Карбоксиліну», насамперед в Україні, Молдові, Латвії та Росії. Виробництво і використання його продовжувалось до розпаду СРСР.

Під керівництвом М. Ф. Гулого було розроблено технологію промислового виробництва i застосування високоочищених ензимів глюкозооксидази і каталази $[11,12]$ та створення на їх основі технології пероксидно-каталазного знебарвлення крові тварин, який було широко впроваджено в практику на м'ясокомбінатах країни для одержання високоякісного харчового протеїну як джерела цінної добавки до ковбас. Для широкомасштабного виробництва глюкозооксидази і каталази $з$ Penicillium vitale було побудовано цех на Косарському спиртовому заводі Черкаської області.

Не менш вагомими є наукові розробки Максима Федотовича Гулого, які знайшли впровадження в медицину. Результатом спільної роботи зі знаними українськими мікробіологами було розроблення і налагодження виробництва медичного препарату - антибіотика $3 \boldsymbol{P}$. vitale niд назвою «Мікроцид», який широко застосовувався в медичній практиці.

Після деякої модифікації препарату «Карбоксилін», створеного, як відзначалося вище, для підвищення продуктивності сільськогосподарських тварин, було розроблено препарат «Намацит», який пройшов клінічні випробування і рекомендований для практичного застосування як адаптогенний препарат [13].

Дослідження алкоголізму й наркоманії показали, що це хвороби обміну речовин. Виходячи 3 цього, М. Ф. Гулий зі співробітниками розробили препарат «Медихронал» [14]. Одержане ними наукове обгрунтування використання «Медихроналу» для лікування алкоголізму дозволило переконати керівництво ЗАТ «Фармацевтична фірма «Дарниця» впровадити його у виробництво i успішно випускати в промислових обсягах (за ліцеензійним договором 3 Інститутом біохімї ім. О. В. Палладіна). Зараз препарат «Медихронал» можна придбати в аптеках України.

Беручи до уваги сумісну дію «Медихроналу» i «Намациту», М. Ф. Гулий розробив i запропонував у виробництво препарат антинаркотичної дії - «Медицит». Але впровадити його у виробництво (до речі, як і «Намацит») поки що не вдається.

Наступне покоління вчених Інституту, науковий шлях яких тільки розпочинався у 60-70-і роки, прийняли естафету від своїх вчителів i гідно продовжили і продовжують їхні традиції.

Так, внаслідок наукоємних фундаментальних досліджень у відділі молекулярної імунології під керівництвом проф. С. В. Комісаренка на основі бісфосфонатів було створено декілька прототипів медичних препаратів. Було синтезовано поліуретанову композицію, яка правила за іммобілізований імуномодулятор iз місцевим протизапальним та імуносупресорним ефектом [15]. Також було доведено протипухлинну активність динатрієвої солі метиленбісфосфонової кислоти і запропоновано новий протипухлинний препарат «МЕБІФОН» [16], який успішно пройшов всі клінічні випробування і зараз його випускає ВАТ «Фармак» $у$ Kuєвi.

За ініціативою та під керівництвам С. В. Комісаренка (зав. відділом молекулярної імунології Інституту біохімії ім. О. В. Палладіна НАН України) за підтримки наукового відділу Центрального військово-медичного управління МО СРСР відразу після аварії на Чорнобильській атомній станції (ЧАЕС) було організовано i проведено на найсучаснішому на той час науковому рівні (протокова цитофлуориметрія 3 використанням моноклональних антитіл, виділення окремих субпопуляцій лімфоцитів, електронна мікроскопія тощо) дослідження стану імунітету в людей («ліквідаторів»), які працювали на ліквідації наслідків аварії. Внаслідок комплексного обстеження їх вже наприкінці 1986 - на початку 1987 р. С. В. Комісаренком зі співробітниками було вперше в світі продемонстровано, що низькі дози сумарної радіації (до 25 бер), спричинюють істотне зниження протипухлинного i противірусного імунітету в «ліквідаторів», зокрема кількості 
та функціональної активності клітин - природних кілерів (NK cells), що відповідають за протипухлинний та противірусний імунітет. Одержані результати було підтверджено повторними обстеженнями цих самих осіб через певний період, коли не було впливу на людей «радіаційного» стресу, а також в експериментах 3 еквівалентними дозами радіації на мавпах. Таке пригнічення «природного» імунітету С. В. Комісаренко назвав «Чорнобильським СНІДом». Відкриття дозволило, зокрема, переглянути дози радіації, що вважалися безпечними для здоров'я людей.

Один з авторів цієї статті, С. В. Комісаренко, був серед перших в СРСР, хто ввів у дослідження гібридомну техніку одержання моноклональних антитіл (мон-AT). Це дало можливість співробітникам відділу молекулярної імунології виділити і проаналізувати низку антитіл 3 унікальними властивостями. Серед них на особливу увагу заслуговують мон-АТ проти унікальної антигенної детермінанти очищеного протеїнового деривату туберкулінумікобактерій великої рогатої худоби, проти різних епітопів молекул плазміногену, фібриногену і/або фібрину та їхніх фрагментів тощо. Останні є надзвичайно важливими для вивчення антигенної структури протеїнів і механізмів зсідання крові та фібринолізу. Ці дослідження заклали основу для розробки імунобіотехнологічних методів зі створення імунодіагностичних тестів та імунолікувальних препаратів. Особливо активна робота в цьому напрямі розпочалася в 90 -ті роки і продовжується дотепер. Про здобутки і складнощі впровадження в практику одержаних ними результатів буде наведено нижче.

У 1980-1982 рр. співробітниками відділу біохімії вітамінів і коензимів спільно 3 Київським вітамінним заводом (КВ3) розроблено технологію одержання С6-аналога $\boldsymbol{\alpha}$-токоферолу, на основі якого було створено і випробувано два препарати під назвою «Евіт-1» (для перорального або внутрішньом'язового введення за кардіологічних патологій) і «Соевіт-Е» (для застосування як сипкої Е-вітамінної кормової домішки у птахівництві) [17]. На КВ3 було виготовлено його перші дослідні партії. Препарат «Соевіт-Е» за результатами експериментальних випробувань було рекомендовано ВАСГНІЛ до виробничого напрацювання на Київському вітамінному заводі для широких дослідно-промислових випробувань у птахівництві. Однак з розпадом Радянського Союзу ичі роботи було припинено.

Багаторічні дослідження $\mathbf{N}$-ацилетаноламінів (NAE) дали можливість співробітникам відділу біохімії ліпідів під керівництвом чл.-кор. НАН України Н. М. Гулої запропонувати для впровадження у виробництво п'яти найперспективніших розробок, які захищено патентами України на винаходи [18-22]. У 2009 р. Інститут біохімії ім. О. В. Палладіна і ВАТ «Фармак» (м. Київ) підписали Ліцензійну угоду на надання останньому виключної ліцензії на використання вищенаведених п'яти винаходів, захищених патентами України.

Тут потрібно зробити відступ і дати деякі пояснення щодо складнощів, які виникають на стадії практичного застосування розробок Інституту (думаємо, не тільки нашого) після 90-го року, тобто з набуттям Україною незалежності. Дійсно, ця, на наш погляд, парадоксальна ситуація виглядає таким чином, що під час впровадження своїх розробок у практику Інститут стикається із труднощами. Наприклад, фармацевтичні підприємства, до яких звертається Інститут для впровадження своїх інноваційних розробок, здебільшого відмовляють у такому співробітництві. Ці підприємства, не маючи зовнішніх інвестицій для інноваційної діяльності, пояснюють свою відмову великими власними фінансовими ризиками за впровадження інноваційного продукту, до яких не готові. Навіть таке відоме фармацевтичне підприємство як ВАТ «Фармак», з яким ще в 2009 р. Інститут уклав ліцензійний договір на використання винаходів Інституту з виробництва та реалізації конче необхідних населенню України ефективних препаратів кардіологічного профілю, призупинило їх впровадження 3 поясненням «до покращення фінансового та інноваційного клімату в державі». А йде вже 2018-й.

Звичайно, інноваційну діяльність Інституту біохімії ім. О. В. Палладіна, як і інших установ Національної академії наук України, неможливо розглядати у відриві від загального стану суспільства та економіки в державі. Тож розглянемо деякі ¥ї аспекти.

Слід зазначити, що наразі в Україні $\epsilon$ необхідна правова база для інноваційного розвитку. Свого часу було прийнято низку законів 
та інших законодавчих нормативних документів, що мають велике значення для розвитку ринку наукової продукції і комерціалізації наукових розробок [23-30].

Проте ці законодавчі акти так і не стали дієвим інструментом комерціалізації вітчизняних наукових розробок. Сьогодні не виконуються основні положення Закону України «Про освіту» [31], в якому зазначено, що витрати на освіту мають становити 10\% ВВП, і Закону України «Про наукову і науково-технічну діяльність» [32], де вказано, що витрати на наукову і науково-технічну діяльність мають бути на рівні 1,7\% ВВП.

Інновачійний процес, за визначенням американського дослідника Б. Твісса, - ие перетворення наукового знання, наукових ідей, винаходів у фізичну реальність (нововведення), яка змінює суспільство. В основі інноваційного процесу лежить створення, впровадження $і$ поширення інновацій, необхіднии властивостями яких $\epsilon$ науково-технічна новизна, практичне їх застосування і комериійна реалізованість з метою задоволення нових суспільних потреб [33].

Досвід розвинених країн світу показує, що інновації справляють незворотний вплив на прискорене економічне зростання країни. Такий вплив інновацій на економіку відбувається лише за узгодженості інноваційної політики 3 науково-технічною, бюджетно-фінансовою, грошово-кредитною, промисловою та зовнішньоекономічною політикою та за умови єдності інтересів і встановлення злагоджених стосунків між суспільством, державою, владою, бізнесом та іншими громадськими і науковими інституціями на платформі національної інноваційної системи [34].

Залучення та раціональне використання інвестицій - найшвидший шлях до піднесення економічного розвитку держави на новий рівень. Інновації у поєднанні 3 інвестиціями дають мультиплікативний ефект, не лише збільшуючи кількість робочих місць і обсяги виробленої продукції, а й знижуючи вартість одиниці продукції, покращуючи їі якість, підвищуючи рентабельність виробництва, умови праці та іiі продуктивність [35].

Необхідною умовою впровадження інноваційних розробок на ринок $є$ процес комерціалізації. Довгостроковий комерційний ефект для підприємства від інновації можливий лише в тому разі, коли всі етапи комерціалізації виконані вчасно та якісно. На етапі створення і впровадження інновація потребує значної державної підтримки.

До цього часу інноваційний розвиток в Україні не став одним із головних чинників зростання національної економіки. На жаль, Україна продовжує розвиватися як країна з високою часткою сировинних галузей промисловості. Стан інноваційної діяльності в Україні більшістю експертів-науковців визначається як кризовий і такий, що не відповідає сучасному рівню розвитку інноваційних процесів у країнах, для яких інноваційний розвиток $є$ ключовим вектором економічної стратегії [36].

Руйнівно вплинула на розвиток наукової сфери некомпетентна державна політика проведення неоліберальних ринкових реформ (приватизація, трансформація бюджетної, податкової, кредитної та інших фінансовоекономічних систем) фактично без врахування науково-технологічного фактора та його впливу на ефективність і конкурентоспроможність вітчизняної економіки. У відношенні до науки здійснювалась безперспективна політика «виживання» існуючого науково-технічного потенціалу замість його оновлення та якісного покращення для приведення у відповідність із потребами ринкової економіки [35].

Впродовж останніх років в Україні було зроблено спроби щодо гармонізації законодавства України в галузі охорони прав інтелектуальної власності згідно із законодавством Свропейського Союзу, які мали б дати поштовх інноваційному розвитку країни.

Позитивні тенденції, які спостерігалися протягом кількох років, мали переважно тимчасовий характер і змінювалися протилежними зрушеннями в економіці, що характеризує інноваційні процеси в Україні як нестійкі та позбавлені чітких довгострокових стимулів для інноваційної діяльності. За останні роки рівень інноваційної активності промислових підприємств істотно знижувався. Так, у 2011 р. інноваційною діяльністю в промисловості України займалося близько 12\% підприємств від їх загальної кількості, тоді як у 2002 р. близько 15\%, а в 2000 р. питома вага підприємств, які займалися інноваційною діяльністю, становила 18\%. Для порівняння у США, Японії, Німеччині й Франції частка інноваційних 
підприємств становить 70-80\% від їх загальної кількості [38].

Багато експертів в Україні вважають, що головною причиною гальмування інноваційного розвитку в країні $є$ дефіцит фінансових ресурсів. Поза тим, 3 причини платоспроможності відбувається спад попиту на науково-технічну продукцію $з$ боку підприємницького сектору, погіршення якісних характеристик наукових кадрів і зниження матеріально-технічної бази досліджень, недостатність професіоналів для ïx здійснення та інші не менш важливі причини [39].

Незважаючи на всі ці негативні i, начебто, об'єктивні причини, науковці Інституту біохімії ім. О. В. Палладіна докладають багато зусиль, аби впровадити у виробництво свої наукоємні і здебільш унікальні розробки. Сьогодні на фармацевтичному ринку України представлені такі інноваційні продукти, що були розроблені в Інституті біохімії ім. О.В Палладіна:

МЕДИХРОНАЛ - унікальний багатокомпонентний антиалкогольний препарат, який: впливає на основні патогенетичні механізми формування алкоголізму, нормалізує обмін етанолу та приводить до детоксикації організму, активізує функціональну активність центральної нервової системи у хворих. $\mathrm{He}$ містить чужорідних для організму речовин, складається виключно з нормальних метаболітів, які постійно беруть участь в обміні речовин організму [40]. На ринку України з 2000 p.

МЕБІФОН - лікувальний засіб із протипухлинною та імуномодулюючою дією. Рекомендований для лікування раку молочної та передміхурової залоз. Виявляє виражений антиметастатичний ефект за відсутності пригнічення системи кровотворення, чинить імунотропну дію, яка дозволяє впливати на патологічні зміни процесів імуногенезу. Виявляє протинабряковий та жарознижувальний ефект, а також виражену анальгетичну дію, яка $є$ дуже важливою для подолання запалень і больових синдромів в онкохворих [41]. На ринку України з 2002 р.

МЕТОВІТАН - комплексний лікарський засіб, який стабілізує найуразливіші ланки клітинного метаболізму, підвищуючи життєстійкість організму. Призначений для профілактики та у складі комплексної терапії захворювань печінки: неалкогольного та алкогольного стеатогепатозу, уражень печінки токсични- ми хімічними речовинами (миш'як, хлороформ, бензол) та внаслідок застосування лікарських препаратів (у тому числі антибіотиків). Застосовується в післяопераційний період та в період одужання після перенесених захворювань, зокрема інтоксикацій різного генезу, а також у комбінованій терапії в разі хронічного алкоголізму та підвищеногоу розумового навантаження, особливо в несприятливих умовах навколишнього середовища. Підвищує опірність організму до інфекційних захворювань, у тому числі застудних.

Вітамінно-мінеральний препарат МЕТОВІТАН виявляє комплексну дію: гепатопротекторну, енергостимулювальну та кардіопротекторну [42]. Не має аналогів в Україні та країнах СНД. На ринку України з 2017 р.

КОРЕКТИН - добавка дістична на основі гліцину, призначена для використання в раціоні харчування населення. Характеризується поліфункціональним ефектом щодо процесів остеогенезу та внутрішньоклітинного метаболізму. Може бути використана у разі порушень кісткової тканини (остеопорози, осталгії, початкові стадії деформуючого артрозу), а також при хронічних гепатитах різної етіології. Позитивно впливає на органічну й мінеральну складові кістки, активує анаболічні процеси, посилює регенерацію кісткової тканини, покращує адгезивно-агрегаційні властивості тромбоцитів, мобілізує антибактеріальний захист за рахунок гранулоцитів крові, запобігає кровотечі стінок кровоносних судин, має детоксикаційні властивості. Також сприяє зменшенню психоемоційного напруження, підвищенню розумової працездатності, покращенню сну, виявляє помірні нейропротекторні та антистресові властивості, зменшує токсичну дію алкоголю [43]. На ринку України з 2017 р.

ГЛІЦИВІТ С - добавка дієтична на основі гліцину та вітаміну С, призначена для використання в харчуванні населення як дієтична добавка до раціону харчування. Може використовуватися для нормалізації структурнофункціонального ушкодження кісткової тканини різної етіології. Позитивно впливає на органічну й мінеральну складові кістки, активує біосинтетичні процеси, нормалізує синтез колагену, уповільнює процеси старіння організму, посилює регенерацію кісткової та сполучної тканини, мобілізує антибактеріальний та 
антивірусний захист, запобігає ламкості кровоносних судин, має детоксикаційні властивості. Сприяє підвищенню розумової працездатності, покращенню сну, виявляє протизапальні властивості, помірні нейропротекторні та антистресові властивості, підсилює захисні реакції організму (гуморальний імунітет), сприяє зменшенню токсичної діі алкоголю. На ринку України з 2017 р.

Але це, як мовиться, «краплина в морі». Наразі Інститут має великий доробок (portfolio) діючих винаходів і корисних моделей, впровадження яких у медицину та фармакологію було б здатне забезпечити населення України якісними вітчизняними лікарськими засобами для ефективного лікування багатьох розповсюджених захворювань. А нові діагностикуми, які розроблені науковцями Інституту, могли би дати в руки лікарів засоби, за допомогою яких можна 3 високою точністю на ранніх стадіях виявляти загрозу тяжких захворювань, таких як інфаркт, інсульт, тромбоемболія легеневої артерії, туберкульоз, дифтерія. Профілактика та своєчасне лікування цих захворювань на ранніх стадіях багатьом людям може зберегти життя. Впровадження вітчизняних фармацевтичних препаратів і діагностикумів дало б можливість державі частково відмовитись від імпортних препаратів, що закуповуються за іноземну валюту, i, таким чином, заощадити державний бюджет.

На сьогодні Інститут має такі готові до впровадження перспективні інноваційні розробки:

Гемостатичний комбінований засіб для зупинки масивних кровотеч, у тому числі за гемофілії. Призначений для негайної зупинки масивних кровотеч під час хірургічних втручань, первинної медичної допомоги в разі поранень та зовнішніх кровотеч за гемофілії; складається 3 перев'язувального матеріалу медичного призначення (спанлейс-тканина або активований волокнистий вуглецевий матеріал), на якому нековалентно іммобілізовано ензимний активатор системи зсідання крові, виділений 3 отрути ефи багатолускової (Echis multsiquamatus); під час контакту ензимного активатора системи зсідання крові безпосередньо 3 кров'ю людини активується протромбін із наступною активацією фактора XIII і стабілізацією згустку; надійно зупиняє масивну кровотечу, завдяки високій сорбційній здатності ефективно поглинати вміст токсичних речовин різної молекулярної маси, включаючи продукти протеолізу i термічної денатурації протеїнів, біогенні аміни i медіатори запалення, бактеріальні токсини, сприяє покращенню місцевого гемостазу, купіруванню травматичного набряку, зниженню інтенсивності місцевої та загальної запальної реакції, попередженню розвитку ускладнень, зупиняючи кровотечу без подразнення рани. Цей гемостатичний комбінований засіб рекомендовано застосовувати, зокрема за гемофілії, в цивільних і військових медичних закладах, а також у польових умовах під час надання первинної медичної допомоги. Засіб розроблено у співпраці з Інститутом експериментальної патології, онкології і радіобіології ім. Р. С. Кавецького НАН України та Інститутом фізіології ім. О. О. Богомольця НАН України [44].

Імунодіагностична тест-система для кількісного визначення розчинного фібрину в плазмі крові людини. Призначена для ранньої діагностики загрози тромбоутворення 3 метою попередження інфарктів, інсультів, тромбозів і тромбоемболій та для моніторингу антитромботичної терапії. Дозволяє 3 високою точністю визначати концентрацію розчинного фібрину - головного маркера активації системи зсідання крові та загрози тромбоутворення, який утворюється з фібриногену за дії тромбіну в присутності інших протеїнів плазми крові. Концентрація розчинного фібрину підвищується за серцево-судинних захворювань (ДВ3-синдром, ішемічна хвороба серця; інфаркт міокарда, тромбоз глибоких вен, тромбоемболія легеневої артерії та ін.); онкологічних захворювань, за цукрового діабету, після хірургічних втручань, під час вагітності, в людей віком старше 60 років та ін. Технічні характеристики: висока чутливість (0,5 $\pm 0,1$ мкг/мл), специфічність (98\%), швидкість виконання аналізу - 3 години; автоматичне кількісне визначення розчинного фібрину; тривалий час зберігання компонентів тест-системи. Переваги: використання високоспецифічних до розчинного фібрину моноклональних антитіл власного виробництва. Не має аналогів в Україні та країнах СНД. Рівень готовності розробки. Пропозиції для комерціалізації: виготовлено експериментальні серії тест-системи «DIA®Фібрин розчинний», які успішно апробовані в провідних клініках України. Дослідні зразки 
виготовлено разом із ПрАТ «НВК «Діапрофмед» [45].

\section{Імунодіагностична}

тест-система

для кількісного визначення D-димеру
(DD) в плазмі крові людини. Призначена для своєчасного виявлення або виключення процесу утворення тромбу в кров'яному руслі, зокрема в кардіологічній, хірургічній, акушерській, комбустіологічній, онкологічній та ендокринологічній практиці, 3 метою попередження та своєчасного лікування тромботичних судинних та серцево-судинних хвороб - однієї 3 основних причин смертності населення в усьому світі. Дозволяє з високою точністю визначати концентрацію D-димеру одного з основних маркерів тромбоутворення та фібринолізу - найбільшого кінцевого фрагмента, який утворюється за розщеплення плазміном полімерного фібрину, стабілізованого фактором XIIIa. Технічні характеристики: висока чутливість визначення D-димеру $(30 \pm 6$ нг/ мл), специфічність (98\%), швидкість виконання аналізу (3 години), автоматичне кількісне визначення D-димеру, тривалий час зберігання компонентів тест-системи. Переваги: використання високоспецифічних до D-димеру моноклональних антитіл власного виробництва. Не має аналогів в Україні та країнах СНД. Рівень готовності розробки. Пропозиції для комериіалізації: виготовлено експериментальні серії тест-системи «DIA®-D-димер», які успішно апробовані в провідних клініках України. Дослідні зразки виготовлено разом із ПрАТ «НВК «Діапрофмед» [46].

\section{Імунодіагностична}

тест-система для кількісного визначення фібриногену в плазмі крові людини. Призначена для діагностики стану системи зсідання крові, у тому числі в кардіологічній, хірургічній, акушерській, комбустіологічній, онкологічній та ендокринологічній практиці з метою попередження тромботичних судинних і серцево-судинних захворювань - однієї з основних причин смертності населення в усьому світі. Дозволяє 3 високою точністю визначати концентрацію фібриногену - центрального протеїну системи зсідання крові та розчинного попередника полімерного фібрину, що формує фібриновий каркас тромбу, який взаємодіючи із тромбоцитами, сприяє їх агрегації, що $є$ першим етапом в утворенні тромбоцитарної гемостатичної пробки. Концентрація фібриногену в плазмі крові підвищується за серцево-судинних захворювань, запальних процесів, травм, злоякісних утворень, інфекційних захворювань та інших патологій. Технічні характеристики: висока

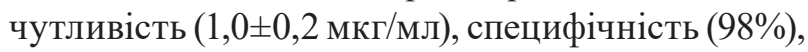
швидкість виконання аналізу (3 години); автоматичне кількісне визначення фібриногену; тривалий час зберігання компонентів тест-системи. Переваги: використання високоспецифічних до фібриногену моноклональних антитіл власного виробництва; тест-система дозволяє з високою точністю визначати концентрацію фібриногену в присутності інших протеїнів плазми крові, розведеної в 200 разів. Не має аналогів в Україні та країнах СНД. Рівень готовності розробки. Пропозииіі для комериіалізації: виготовлено експериментальні серії тест-системи «DIA® Фібриноген», які успішно апробовані в провідних клініках Києва. Дослідні зразки виготовлено разом із ПрАТ «НВК «Діапрофмед» [47].

\section{Імунодіагностична}

тест-система для одночасного кількісного визначення фібриногену, розчинного фібрину та D-димеру в плазмі крові людини. Призначена для одночасного кількісного визначення фібриногену, розчинного фібрину та D-димеру в плазмі крові людини з метою комплексної діагностики стану системи гемостазу, виявлення або виключення ризику чи наявності тромбоутворення за різних патологій на ранніх етапах захворювання, для діагностики ДВЗ-синдрому і моніторингу антитромботичної та фібринолітичної терапії, в тому числі в кардіологічній, хірургічній, акушерській, комбустіологічній, онкологічній та ендокринологічній практиці. Технічні $x a-$ рактеристики: висока чутливість $(0,5 \pm 0,1$ мкг/ мл); специфічність (98\%), швидкість виконання аналізу (3 години); автоматичне кількісне визначення параметрів; тривалий час зберігання. Переваги: використання високоспецифічних моноклональних антитіл власного виробництва. Не має аналогів у світі. Рівень готовності розробки. Пропозииії для комериіалізації: одержано позитивні результати апробації тест-системи «DIA®-Гемостаз» в провідних клініках України. Дослідні зразки виготовлено разом із ПрАТ «НВК «Діапрофмед».

Імуноферментна тест-система для контролю протидифтерійного імунітету в популяції. Призначена для скринінгу 
протидифтерійного імунітету в популяції та оцінки рівня антитоксичного імунітету у хворих під час перебігу інфекції. Розробка може бути застосована для вдосконалення диференційної діагностики дифтерії та для моніторингу стану захищеності населення від дифтерії. Технічні характеристики: тест-система базується на імуноензимному аналізі. До складу імуносорбенту входять рекомбінантні неактивні субодиниці А та В дифтерійного токсину власного виробництва. Тест-система дозволяє одержати дані з високою точністю, проста та надійна в роботі. Переваги: можливість визначати рівень антитіл до кожної із субодиниць дифтерійного токсину окремо, що має діагностичне значення, тому що рівень антитіл до В-субодиниці токсину характеризує протективний імунітет, а наявність антитіл до А-субодиниці свідчить про можливий контакт зі збудником (носійство або хворобу). Власне одержання рекомбінантних неактивних субодиниць А та В дифтерійного токсину з мінімальними затратами часу, ресурсів та 3 високим виходом цільового продукту. Рівень готовності розробки: разом із ПрАТ «НВК «Діапрофмед» виготовлено дослідні зразки [48].

Тест-система імуноферментна для виявлення антитіл до Mycobacterium bovis. Призначена для швидкого кількісного визначення в сироватці або плазмі крові великої рогатої худоби антитіл до M. bovis з метою діагностики інфікованості збудником туберкульозу тварин на рівні стад, тварин із латентним перебігом туберкульозу, а також тварин, які виявляють алергічну реакцію на туберкулін, і $є$ прихованими джерелами збудника туберкульозу. Технічні характеристики: тест-система складається 3 імуносорбенту, виготовленого на основі високоімуногенного та високоспецифічного до антитіл проти M. bovis рекомбінантного генетично злитого антигену MPB63-MPB83 M. bovis, який одночасно має антигенні властивості двох індивідуальних протеїнів $M$. bovis: MPB63 і МРВ83, що підвищує чутливість тестсистеми. Переваги: використання генетично злитого антигену MPB63-MРВ83 M. bovis власного виробництва; тест-система проста, дозволяє одержати точні результати та надійна в роботі. Рівень готовності розробки: одержано державну реєстрацію ТУ. «Інноваційновиробничою компанією «Рамінтек» виготовлено експериментальні серії тест-системи, які успішно апробовані в Україні [49].
Тест-система імуноферментна для виявлення антитіл до Mycobacterium tuberculosis. Призначена для виявлення антитіл до збудника туберкульозу людини M. tuberculosis в сироватці або плазмі крові людини методом непрямого твердофазного імуноензимного аналізу (IEA). Технічні характеристики: у складі імуносорбенту використано високоімуногенний i високоспецифічний до антитіл проти M. tuberculosis рекомбінантний генетично злитий антиген МРТ63-MPT83 M. tuberculosis власного виробництва. Антиген МРТ63-МРТ83 має антигенні властивості двох індивідуальних діагностично важливих антигенів M. tuberculosis: MPT63 і MPT83, за рахунок збільшення маси виявляє підвищені сорбційні властивості, що забезпечує краще експонування його епітопів порівняно 3 окремими складовими та збільшує чутливість тест-системи. Переваги: використання генетично злитого антигену MPT63-МРТ83 M. tuberculosis власного виробництва; тест-система доступна, точна, проста та надійна в роботі, придатна для застосування в широкій медичній практиці: забезпечує швидке кількісне визначення антитіл до M. tuberculosis в сироватці або плазмі крові людини, що має важливе значення для своєчасного виявлення пацієнтів, інфікованих M. tuberculosis, та пацієнтів із латентним перебігом цієї хвороби. Рівень готовності розробки. Пропозииіі для комериіалізації: в Інституті біохімії ім. О. В. Палладіна НАН України виготовлено експериментальні серії тест-системи [50].

$$
\text { Лікарські засоби на основі }
$$

$\mathbf{N}$-ацилетаноламінів. $\mathrm{N}$-ацилетаноламіни унікальний клас речовин, притаманних живим організмам. У синтетичних $\mathrm{N}$-ацилетаноламінів виявлено низку нових біологічно активних властивостей, які дозволили знайти їм застосування як лікарським засобам для профілактики й лікування широкого кола захворювань, а саме: атеросклерозу; ішемічної хвороби серця; стенокардії спокою та напруги; гострого коронарного синдрому; функціональних та органічних уражень печінки; цукрового діабету 1-го та 2-го типів; термічних опіків шкіри i лікування та профілактики опікової хвороби; грипозної інфекції; вірусного гепатиту С (nодано заявку), герпесу 1-го та 2-го типів (подано заявку); алергічних реакцій та неспецифічного запалення; алкогольної інтоксикації; розладів 
чоловічої статевої системи; опійної наркоманії, інтоксикацій ЦНС; в супроводжуючій протипухлинній терапії для гальмування росту пухлини та метастазування за умов розвитку неоплазми і проведення протипухлинної терапії цитотоксичними препаратами; для лікування станів, що супроводжуються ішемією та гіпоксією органів і тканин, реперфузійним синдромом, оксидативним стресом, інтоксикаціями, наркотичною залежністю; для запобігання розвитку незворотних структурних змін мембран; для істотного підвищення резистентності органів і тканин до дії ушкоджуючих чинників; консервації донорських органів тощо [51-56]. Рівень готовності розробок. Пропозииї для комериіалізації: укладено Ліцензійний договір про надання виключної ліцензії на використання об'єктів права інтелектуальної власності (пат. № 77182 UA, № 77278 UA, пат. № 81861 UA, пат. № 85522 UA, пат № 85523 UA). Фірма-ліцензіат BAT «Фармак», м. Київ, Україна, строк дії від 28.12.2009 до 31.12.2023; на жаль, призупинено впровадження цих розробок, як ми вже писали вище, 3 поясненням виробника: до покращення фінансового та інноваційного клімату в державі. Спосіб одержання автологічного фібринового гелю для стимуляції регенерації кісткових $i$ м'яких тканин i зниження інтенсивності запальних процесів. Рекомендовано для застосування в ортопедії, травматології, хірургії. Технічні характеристики: автологічний фібриновий гель утворюється 3 плазми крові пацієнта та активатора протромбіну - ензиму екамуліну 3 отрути ефи багатолускової; стимулює регенерацію кісткових і м'яких тканин, знижує інтенсивність прояву запальних процесів, знижує алерго- та імуногенність і підвищує ефективність лікування. Переваги: одностадійність одержання автологічного фібринового гелю з плазми крові пацієнта безпосередньо перед клінічним застосуванням, що значно спрощує технологію та скорочує час його одержання порівняно з аналогами; невеликий за об'ємом відбір крові пацієнта - 10-20 мл (проти 60-150 мл у найближчого аналога); швидке утворення водо- та повітронепроникного автологічного фібринового гелю на ураженій поверхні (45-100 с від моменту змішування компонентів); інфекційна безпечність завдяки використанню ензиму екамуліну як активатора протромбіну (замість тромбіну як в аналогів); неантигенність та відсутність подразнювальної дії автологічного фібринового гелю на прилеглі тканини; простота нанесення аплікації, високий ступінь моделювання ураженої поверхні, висока щільність прилягання до тканин фібринового гелю; стимулювання регенерації кісткових i м'яких тканин та зниження інтенсивності запальних процесів; використання набору для одержання автологічного фібринового гелю [57].

Лікувально-профілактичний вітамінний препарат $\mathbf{D}_{3}-\mathbf{E}$ білковий комплекс. Призначення розробки. Вітамін $\mathrm{D}_{3}$-Е протеїновий комплекс - удосконалений відомий препарат «ВІДЕЇН 3», призначений для профілактики i лікування рахіту та рахітоподібних захворювань у дітей, остеопатій різного генезу, D-гіповітамінозів у вагітних жінок, після операцій з приводу заміни суглобів, ортопедичних деформацій із уповільненою консолідацією в разі перелому кінцівок, у комплексній терапії ревматоїдного артриту та ін. Технічні характеристики: технологія одержання забезпечує підвищення ємності зв'язування вітамінів $\mathrm{D}_{3}$ та $\mathrm{E}$ 3 казеїном, збільшення терміну зберігання комплексу в 2 рази та знищення бактерій. Синергізм дії компонентів комплексу підвищує на 30\% ступінь забезпеченості організму вітаміном $\mathrm{D}_{3}$, чим збільшує його профілактичний та лікувальний ефект. Переваги: бактеріальна чистота субстанції, виключно природні компоненти, не містить консервантів і синтетичних стабілізаторів; має великий термін зберігання 5 років; високу біодоступність, терапевтичну ефективність і якість. Рівень готовності розробки. Пропозииії для комериіалізащії: розроблено аналітичну нормативну документацію, технологію одержання субстанції та готової лікарської форми вітамін $\mathrm{D}_{3}$ - $\mathrm{E}$ протеїнового комплексу [58].

«МЕБІВІД»-фармацевтична композиція для лікування захворювань кісткової тканини. Призначена для лікування захворювань опорно-рухового апарату, які супроводжуються розрідженням кісткової тканини - остеопорозом. Технічні характеристики: активними компонентами цієї композиції $€$ неорганічні й органічні складові, зокрема кальцій, вітамін $\mathrm{D}_{3}$ та дигідрат динатрієвої солі метиленбісфосфонової кислоти у фізіологічно прийнятній дозі. Переваги: на відміну від існуючих вітчизняних i зарубіжних аналогів композиція МЕБІВІД 
виявляє високу фізіологічну активність, легко й швидко метаболізується, добре переноситься організмом, регулює структурні та метаболічні процеси клітин кісткової тканини, позитивно впливає на органічну й мінеральну складові кісток, тобто на регенерацію кісткової тканини, виявляє ефект комбінованої дії. Результатом застосування препарату «МЕБІВІД» є збільшення кісткової маси, усунення остеопорозу, а відтак - зменшення ризику перелому як кісток кінцівок, так і хребців. Рівень готовності розробки. Пропозиції для комеричіалізації: розроблено аналітичну нормативну документацію на «МЕБІВІД», капсули»; проект технологічного регламенту, звіт про специфічну ефективність препарату «МЕБІВІД» для лікування остеопоpoзy [59].

\section{КАЛЬМІВІД-М - вітамінно-міне-} ральний препарат для лікування остеопорозу. Призначений для лікування остеопорозу та профілактики захворювань, пов'язаних із розрідженням кісткової тканини. Технічні характеристики: вітамінно-мінеральний препарат «КАЛЬМІВІД-М» $є$ високоефективним у лікуванні структурно-функціонального розладів стану кісткової тканини та епіфізарного хряща, до складу якого входять: вітамін $\mathrm{D}_{3} \mathrm{y}$ вигляді протеїнового комплексу з казеїном, що надає йому підвищену стійкість та запобігає утворенню токсичних продуктів його окислення, вітамін Е і мінеральні компоненти кальцію, цинку, міді та марганцю. Переваги: «КАЛЬМІВІД-М» є біодоступнішим щодо іонів кальцію та ефективніше нормалізує фосфорний обмін в організмі порівняно з існуючими аналогами [60].

Водорозчинний препарат вітаміну $\mathbf{D}_{3}$. Призначений для дітей перших місяців життя. Властивості: водорозчинний препарат вітаміну $\mathrm{D}_{3}$ нормалізує обмін речовин, забезпечує повне засвоєння мінеральних компонентів у шлунково-кишковому тракті, регулює їх реабсорбцію в нирках та проліферацію й диференціацію клітин, зміцнює імунну систему, підвищує функціональну активність органів i систем. Переваги: не містить консервантів i стабілізаторів, не виявляє токсичних проявів, має довгий термін зберігання (протягом двох років активність препарату не зменшується), зручніший у використанні для новонароджених, ніж таблетована форма [61].
ОКОВІТАМ - очні краплі. Призначені для нормалізації клітинного обміну в тканинах ока. Властивості: ефективно стимулюють метаболізм в тканинах ока, попереджають патологічні зміни в ньому, зокрема розвиток катаракти. $\mathrm{C}$ стерильним розчином препарату «МЕТОВITAН», який 32017 р. виробляє ЗАТ «Технолог», м. Умань). Рівень готовності розробки. Пропозиції для комериіалізащії: проведені доклінічні випробування на добровольцях на базі клініки Інституту очних хвороб і тканинної терапії ім. В.П. Філатова НАМН України (м. Одеca), які показали високу ефективність препарату. «Оковітам» готується до випуску на хімікофармацевтичному підприємстві ЗАТ «Технолог» (м. Умань) [62].

Препарат для лікування та профілактики серцево-судинних захворювань КАРДІОВІТ. Призначений для лікування та профілактики серцево-судинних захворювань. Властивості: основою препарату $\epsilon$ вітамін $\mathrm{B}_{1}$ (тіамін) та композиція природних біологічно активних речовин, яка стимулює в тканинах організму внутрішньоклітинне утворення біоктивної форми тіаміну - тіаміндифосфату (кокарбоксилази), що в цілому приводить до активації біоенергетичного обміну в тканинах, а у разі із серцевим м'язом - до стабілізації його функціонування. КАРДІОВІТ підвищує ефективність використання не лише вітамінів $\mathrm{B}_{1}$ $\mathrm{i} \mathrm{E}$, які входять до його складу, але й інших вітамінів, що містяться в тканинах. Препарат також поліпшує засвоєння вітамінів із продуктів харчування за рахунок активації транспортувальних систем, підвищує рівень відновленого глутатіону, регулює синтез і накопичення жиру та покращує стан серцевосудинної системи. Переваги: порівняно зі своїм найближчим аналогом КОКАРБОКСИЛАЗОЮ КАРДІОВІТ має переваги за такими параметрами: вільний тіамін (тіамінхлорид, тіамінбромід або інша форма вітаміну $\mathrm{B}_{1}$ ), що $є$ основною складовою КАРДІОВІТУ, легко проходить крізь клітинні мембрани і відразу фосфорилується на відміну від свого аналога, до складу якого входить тіаміндифосфат, транспорт якого крізь клітинні мембрани є ускладненим і відбувається лише після дефосфорилування; композиція препарату КАРДІОВІТ стимулює ендогенний синтез тіаміндифосфату та активує обмін тіаміну; КАРДІОВІТ вводиться в організм не 
внутрішньом'язово, а per os у вигляді таблеток або капсул; вартість готової форми нового препарату значно нижча, ніж його аналога [63].

ЕНЕРГОВІТАМ - комплексний препарат для підвищення внутрішньоклітинного енергетичного обміну в організмі. Призначений для використання в медицині та експериментальній біології як препарат, що забезпечує інтенсифікацію біосинтезу та функціонування убіхінону (коензиму Q) в організмі, необхідного для відновлення та стимуляції біоенергетичного обміну клітин, порушення якого лежить в основі розвитку широкого спектра патологій. Властивості: препарат підвищує вміст коензиму Q в організмі за рахунок введення попередників його синтезу: вітаміну $\mathrm{E}$ як регулятора біосинтезу убіхінону (коензиму Q), параоксибензойної кислоти (ПОБК) як попередника біосинтезу бензохінонової частини молекули, метіоніну як попередника в реакціях трансметилування на термінальних етапах біосинтезу активної молекули Q та диметилсульфоксиду як транспортера біологічно активних речовин. Переваги: стимуляція біоенергетичного обміну клітин: запезпечує інтенсифікацію ендогенного синтезу коензиму Q власне самим організмом замість екзогенного прийому препаратів коензиму Q, які мають значну вартість, що практикується зараз; значне здешевлення курсу лікування порівняно із вживанням препаратів, що містять коензим Q [64].

Апарат «ГЕЛІКОТЕСТЕР» для неінвазивної експрес-діагностики гелікобактеріозу шлунка. Призначений для неінвазивного виявлення наднормальної кількості бактерій Helicobacter pylori методом прямого уреазного тесту та проведення масового профілактичного обстеження населення на гелікобактеріоз шлунка, в тому числі дітей шкільного віку. Технічні характеристики: апарат «ГЕЛІКОТЕСТЕР» складається 3 детекторної частини на основі датчика на аміак, системи обробки, керування та відображення інформації, вбудованої повітряної помпи для забору повітря. Апарат визначає приріст концентрації аміаку в ротовій порожнині після вживання карбаміду, що $є$ діагностичним параметром, який залежить від кількості бактерій Helicobacter pylori в шлунку. Переваги: висока чутливість методу, низька вартість обладнання, простота у використанні; неінвазивність та швидкість аналізу, можливість ранньої діагностики гелікобактеріозу. Рівень готовності розробки. Пропозичії для комериіалізащії: медичний виріб аппарат «ГЕЛІКОТЕСТЕР» для неінвазивної експрес-діагностики гелікобактеріозу шлунка» зареєстровано в Державній службі України 3 лікарських засобів. Виробник - Інститут біохімії ім. О. В. Палладіна НАН України.

Індикатор вологи ЕН - «Електронна няня». Призначений як сенсорний апарат-детектор на вологу для лікування енурезу в дітей або в пацієнтів різного віку, оснований на методі формування умовного рефлексу пробудження за допомогою спеціальних сигнальних пристроїв («мокрий будильник»). Принцип дії: у разі попадання вологи на поверхню сенсорного датчика відбувається спрацювання електронного пристрою, включається світлова та звукова сигналізація. Ці сигнали, з одного боку, можуть примусити пацієнта прокинутися від сну, що $є$ основним механізмом лікування енурезу. Крім того, індикація апарата може бути корисною для батьків дитини або персоналу, який обслуговує пацієнта. Датчик на вологу виготовлений у двох розмірах: менший розмір сенсорного апарата призначений для локального застосування, наприклад, для розміщення у пелюшках дитини, більший - для розміщення під простирадлом у ліжку. Технічні характеристики: має дві струмопровідні доріжки в одній площині; наявність зазору між ними формує значний опір цієї системи, за попадання вологи на її поверхню відбувається шунтування цих доріжок, що призводить до значного зменшення опору; для формування струмопровідного покриття, нанесеного на поверхню тонкої та гнучкої плівки (наприклад, поліетилену), використано два матеріали: срібловмісна та карбонова фарба; товщина поліетиленової плівки - 100 мкм; датчики на вологу мають розміри: $10 \times 10 \mathrm{~cm}^{2}$ та

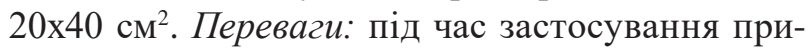
строю енурез минає у двох третин дітей, і приблизно половина дітей, які продовжують застосовувати цей пристрій, залишаються сухими. Курс лікування для більшості дітей триває 6-16 тижнів. Рівень готовності розробки. Пропозииії для комериіалізації: виготовлено експериментальну партію (ТУ У 26.5-05417288-011: 2016). Внесено до бази даних «Технічні умови України». Завершується процес сертифікації апарата. 
Засіб для лікування й профілактики автоімунних деміслінізаційних та нейродегенеративних захворювань центральної $\mathrm{i}$ периферійної нервової системи (розсіяного склерозу). Призначений як комплексний вітамінно-мінеральний препарат для лікування демієлінізаційних захворювань, таких як розсіяний склероз, гострий розсіяний енцефаломієліт, дифузно-дисимінований склероз, гостра та хронічна запальна демієлінізуюча поліневропатія тощо. Властивості: виявляє імуномоделювальну та антиоксидантну дію; здатний покращувати трофіку ушкоджених клітин центральної нервової системи (ЦНС); компенсує метаболічні порушення у хворих на демієлінізаційні захворювання, зокрема розсіяний склероз; призупиняє/сповільнює розвиток демієлінізаційних та нейродегенеративних змін у ЦНС; знижує ризик рецидивів й ускладнень і побічних ефектів за лікування й у разі профілактики демієлінізаційних захворювань $з$ автоімунними механізмами розвитку та характеризуються оксидативним стресом i дисфункцією мітохондрій клітин ЦНС, зокрема за розсіяного склерозу [65].

Спосіб визначення плазміногену в плазмі крові. Дозволяє визначати плазміноген у плазмі крові в нормі та за патологій шляхом визначення часу напівлізису фібринового згустку плазміногеном, активованим стрептокіназою. Технічні характеристики: турбідиметричний метод визначення та автоматична реєстрація часу напівлізису фібрин-мономера, одержаного 3 фібриногену бика; реєстрація зміни світлорозсіювання в процесі полімеризації та гідролізу фібрину за довжини хвилі 350 нм. Переваги: дозволяє автоматично 3 великою точністю визначити час напівлізису фібринового згустку; джерелом фібринового згустку $є$ фібрин-мономер без домішок плазміногену, одержаний 3 фібриногену бика; концентрація фібрин-мономера в реакційному середовищі становить 0,2 г/л, що значно менше, ніж в аналогів; спосіб простий у виконанні; забезпечує високу точність та відтворюваність результатів, стандартне відхилення складає близько $\pm 5 \%$ [66].

$$
\text { Спосіб визначення активності }
$$
нефракціонованих гепаринів та анти-Хафакторної активності низькомолекулярних гепаринів. Призначений для використання у фармацевтичній промисловості для контролю якості субстанцій нефракціонованих гепаринів (НГ) та низькомолекулярних гепаринів (НМГ) i готових лікарських форм на їх основі. Технічні характеристики: для визначення активності гепаринів використовується низькомолекулярний протеїн (протаміну сульфат) на автоматичному титраторі. Переваги: дозволяє автоматично 3 високою точністю визначати об'єм титранту (розчину каліброваного протаміну сульфату), витраченого на титрування розчинів НГ та НМГ $з$ невідомою активністю; дозволяє швидко (протягом 10 хв) визначати активність НГ та анти-Ха-факторну активність НМГ за використання лише одного реагенту порівняно 3 аналогами, за допомогою яких для визначення активності НГ використовують кров тварин та декілька реагентів, а для визначення анти-Ха-факторної активності НМГ використовують реагенти високої вартості: (хромогенний субстрат, антитромбмін III, фактор Ха та спеціальне устаткування); дає можливість визначати активність НГ та анти-Ха-факторну активність НМГ для широкого діапазону значень їх вихідних концентрацій $[67,68]$.

Тест-система для визначення анти-ІІа факторної активності низькомолекулярних гепаринів (НМГ). Призначена для використання у фармацевтичній промисловості для контролю якості субстанцій низькомолекулярних гепаринів (НМГ) і готових лікарських препаратів на їх основі, а також для біохімічних та біологічних досліджень. Технічні характеристики: як реагент використовують бідну на тромбоцити цитратну плазму крові, що $є$ джерелом антитромбіну III і фізіологічного субстрату (фібриногену); проводять реєстрацію утворення фібрину за дії екзогенного фактора ІІа в присутності стандартних зразків НМГ турбідиметричним методом. Переваги: автоматичне визначення анти-ІІа-факторної активності як готових лікарських форм НМГ, так і субстанцій НМГ, із використанням не індивідуальних реагентів високої вартості (хромогенний субстрат та антитромбін III), а бідну на тромбоцити плазму крові людини чи бика, як свіжовиготовлену, так і заморожену або ліофільно висушену, що містить в собі фізіологічний субстрат та антитромбін III; застосовується лише один буферний розчин; характеризується коротким часом виконання аналізу - 1 г (у найближчого аналога - 6 г); має 
доступну вартість; не має вітчизняних та закордонних аналогів [69].

Спосіб прогнозування післяопераційних тромботичних ускладнень. Призначений для прогнозування розвитку післяопераційних тромботичних ускладнень шляхом зіставлення значень концентрацій розчинного фібрину та D-димеру в плазмі крові хворого з урахуванням важливості кожного 3 цих показників та їх кореляції. Опис способу: прогнозування післяопераційних тромботичних ускладнень проводять шляхом зіставлення кількісних змін двох прогностичних маркерів активації системи гемостазу - розчинного фібрину (як основного показника активації системи зсідання крові) та D-димеру (як опосередкованого показника стану системи фібринолізу, дію якої спрямовано на розщеплення фібрину) в процесі післяопераційного лікування хворих та/або в процесі реабілітації,що дає можливість виявити порушення балансу між системами зсідання крові й фібринолізу. За допомогою імуноензимних тест-систем проводять одночасне кількісне визначення концентрації двох прогностичних маркерів активації системи гемостазу: розчинного фібрину та D-димеру до операції та в період післяопераційного лікування та/або реабілітації, далі визначають ступінь порушення динамічної рівноваги в системі гемостазу шляхом зіставлення між собою значень обох параметрів, фіксують кореляцію їх змін, на основі чого прогнозують високу ймовірність післяопераційних тромботичних ускладнень, а саме: за концентрації розчинного фібрину, яка в два і більше разів перевищує норму без одночасного підвищення концентрації D-димеру відносно норми; низьку ймовірність післяопераційних тромботичних ускладнень прогнозують за концентрації розчинного фібрину, яка не перевищує подвійної норми, у разі одночасної присутності D-димеру, концентрація якого вища подвійної норми. Переваги: забезпечує підвищення вірогідності прогнозування розвитку післяопераційних тромботичних ускладнень, високу диференційованість прогнозування та контроль ефективності антитромботичної терапії на всіх етапах лікування та/або реабілітації [70].

Спосіб для експресного визначення рівня інтегральної забрудненості, вмісту токсичних органічних сполук та важких металів в об'єктах довкілля. Дозволяє оцінити сукупну та специфічну (якісну і кількісну) токсичну дію органічних та неорганічних забруднювачів та їх сумішей в об’єктах довкілля з використанням біосенсорних систем. Технічна характеристика: як сенсорні елементи біолюмінесцентного аналізатора використовують тест-штами природних та/або генетично сконструйованих мікроорганізмів, які мають природну або індуковану біолюмінесценцію: Alcaligenes eutrophus T1, Pseudomonas fragi T2, Vibrio fisheri F1, Photobacterium phosphoreum B 7071, Vibrio harvei Ms1, Alcaligenes eutrophus 1239. Клітини зазначених штамів специфічно гасять або збуджують рівень природної чи індукованої біолюмінесценції за дії токсичних забруднювачів. Переваги: висока специфічність визначення, високий рівень чутливості для визначення металів, можливість використання нативного досліджуваного зразка; фіксування біологічно токсичного компонента із загального рівня вмісту забруднювачів; визначення кількості токсичних металів у загальному вмісті їх у зразку; простота виконання й швидкість проведення вимірюваня (3-5 хв); можливість проведення аналізу в польових умовах, відсутність необхідності у висококваліфікованому персоналі; економічність. Розроблено разом 3 Інститутом біоколоїдної хімії ім. Ф. Д. Овчаренка НАН України та Інститутом електродинаміки НАН України [71].

Пристрій для експресного визначення рівня інтегральної забрудненості, вмісту токсичних органічних сполук та важких металів в об'єктах довкілля. Дозволяє якісно й кількісно оцінити сукупну і специфічну токсичну дію органічних та неорганічних забруднювачів та їх сумішей. Реєструє рівень природної або індукованої біолюмінесценції за дії токсичних забруднювачів на сенсорні елементи біолюмінесцентного аналізатора (відповідні специфічні тест-штами природних та/або генетично сконструйованих мікроорганізмів). Технічна характеристика: фотоелектронний перетворювач із вихідним сигналом у вигляді електричного струму, пропорційного рівню біолюмінесценції; перетворювач струм/напруга зі змінним коефіцієнтом перетворення; всі елементи вимірювального каналу, включаючи фотоелектронний помножувач, виготовляються 3 використанням мікроелектронних технологій. Переваги: визначення токсичних для живих систем забруднювачів (традиційні методи дозволяють визначити лише їх загальний вміст без ура- 
хування біологічної токсичності); розширений діапазон вимірювання; зменшення випадкової похибки вимірювання; малі габарити і низьке енергоспоживання; значна частина пристрою може бути уніфікованою 3 вимірювальними приладами іншого призначення, що оптимізує виробництво пристрою, зменшує його вартість i дозволяє підключати до уніфікованих інформаційних систем. Розроблено разом 3 Інститутом біоколоїдної хімії ім. Ф. Д. Овчаренка НАН України та Інститутом електродинаміки НАН України [72].

Отже, як у попередні часи, так і тепер, науковці Інституту біохімії ім. О. В. Палладіна НАН України, незважаючи на всі труднощі інноваційного розвитку в нашій державі, продовжують плідну працю, наслідком якої є значна кількість цінних й унікальних розробок. На наш погляд, впровадження цих розробок потребує серйозної допомоги держави та інвесторів, що дозволить істотно підвищити якість і тривалість життя людей в нашій країні.

На нашу думку, дійовим кроком активізації інноваційної активності в країні має бути забезпечення державної підтримки інноваційного підприємництва.

Аналізуючи інноваційну політику в Україні в цілому, слід відзначити, що в останні роки невеличкі кроки з боку держави в цьому напрямі вже робляться.

Приємно відзначити, що за показниками Глобального інноваційного індексу-2017 Україна посіла 50-е місце серед 127 країн світу, піднявшись на шість рядків порівняно з 2016 роком. Глобальний інноваційний індекс визначають Корнельський університет, школа бізнесу INSEAD і Всесвітня організація інтелектуальної власності. Експерти складають рейтинг на підставі 81 критерію, починаючи з рівня науководослідних і дослідно-конструкторських робіт та кількості патентних заявок до обсягу витрат на освіту. У доповіді також враховують нові політичні показники інноваційної діяльності, включаючи податкові пільги, політику в області імміграції, освіти та інтелектуальної власності [73].

Про збережений потенціал вітчизняної науки свідчить і той факт, що українські вчені бе- руть активну участь у загальноєвропейському та світовому ринках наукових кадрів і наукових розробок та користуються на ньому значним попитом. Проте, висока мобільність наукових кадрів має місце без будь-якої участі держави, тому не використовується в інтересах країни. Поза інтересами країни залишається і численна українська наукова діаспора в зарубіжних наукових структурах. Отже, назріла нагальна необхідність у зламі негативних тенденцій, що склалися в науковій сфері, спрямуванні державної політики на формування якісно нового науково-технічного потенціалу, максимального його використання для переведення вітчизняної економіки на інноваційний шлях розвитку. Для розбудови інтелектуально-орієнтованої економіки і формування суспільства знань в Україні має бути ефективна наука світового рівня, тобто високопродуктивні науковці, інформаційне забезпечення їхної праці та сучасне технологічне оснащення, раціональна організація науково-дослідних, дослідноконструкторських розробок, розвинута система комерціоналізації наукових результатів, інакше кажучи, наука 3 високим інноваційним потенціалом [74].

Уселяє надію на покращення інноваційного клімату в державі створення в 2017 р. при Кабінеті Міністрів України «Ради з інновацій», покликаної створити національне законодавство, стимули й мотивації в науковій сфері, захистити наших учених, існуючі в країні новації та український продукт [75].

На початку літа 2017 р. фахівці МОН України спільно 3 науковцями, представниками бізнесу та громадських організацій розробили проект системної підтримки та розвитку інноваційної діяльності. Нині він реалізується через низку проектів законодавчих актів, які або вже прийняті в першому читанні, або схвалені урядовим комітетом Кабінету Міністрів України. Наприклад, зміни до закону «Про державне регулювання діяльності у сфері трансферу технологій» передбачають субсидії для проектів високотехнологічних виробництв, створених вітчизняними промисловими підприємствами за участю вітчизняних наукових установ або вищих навчальних закладів [76]. 


\section{ИННОВАЦИОННАЯ ДЕЯТЕЛЬНОСТЬ ИНСТИТУТА БИОХИМИИ ИМ. А. В. ПАЛЛАДИНА НАН УКРАИНЫ: ПРОБЛЕМЫ И ПЕРСПЕКТИВЫ}

\section{Г. Г. Луговская, В. М. Данилова, \\ С. В. Комисаренко}

\author{
Институт биохимии им. А. В. Палладина \\ НАН Украины, Киев; \\ e-mail: valdan@biochem.kiev.ua
}

Проведен историко-науковедческий анализ достижений ученых Института биохимии им. А. В. Палладина НАН Украины в изобретательской деятельности для нужд медицины, сельского хозяйства, экологии, промышленности. Проанализированы объекты права интеллектуальной собственности Института; описано перспективные инновационные разработки. На основе проведенного анализа сделан вывод, что изобретательская деятельность научных учреждений, в частности Института биохимии им. А. В. Палладина НАН Украины, и внедрение научных разработок, новейших технологий в производство может обеспечить как предприятиям, так и стране в целом экономический рост и экономию ресурсов, что особенно важно в условиях рынка.

К л ю ч е в ы е с л о в а: инновационная деятельность, изобретательская деятельность, интеллектуальная собственность, авторское свидетельство, патент, иммуноэнзиматические тест-системы, витаминные комплексы.

\section{INNOVATIVE ACTIVITY \\ OF PALLADIN INSTITUTE OF BIOCHEMISTRY OF NAS OF UKRAINE: PROBLEMS AND PROSPECTS}

G. G. Lugovska, V. M. Danilova, S. V. Komisarenko

\section{Palladin Institute of Biochemistry, National Academy of Sciences of Ukraine, Kyiv; e-mail: valdan@biochem.kiev.ua}

A historical and scientific study of the inventive achievements of researchers of Palladin Institute of Biochemistry of NAS of Ukraine for the needs of medicine, agriculture, ecology, industry was car- ried out. Intellectual property objects of the Institute were analyzed, and promising innovative developments were described. Based on the performed analysis, it was concluded that the inventive activity of scientific institutions, in particular, Palladin Institute of Biochemistry of NAS of Ukraine, followed by the introduction of scientific developments and new technologies into industries, can contribute to economic growth of both companies and the country as a whole, as well as to preserving and saving resources that is particularly important in a competitive market.

K eyw ords: innovation activity, inventive activity, intellectual property, author's certificate, patent, immunoenzyme test systems, vitamin complexes.

\section{References}

1. Данилова ВМ, Виноградова РП, Комісаренко СВ. Винахідницька діяльність Інституту біохімії ім. О. В. Палладіна НАН України у 1925-1990 рр. Короткий історичний нарис. Ukr Biochem J. 2015; 87(2): $163-175$.

2. А. с. 67601 СССР, КЛ. 30 H, 330 L. Способ прекращения кровотечений и ускорения заживления ран / А. В. Палладин (СССР). № 3659/342011; заявл. 19.09.42; опубл. 01.01.46.

3. А. С. 15241. Мин.здрав. СССР. Белковый кровезаменитель БК-8 / В.А. Белицер, К.И. Коткова (СССР). - № 0190/460281; заявл. 29.05.53; дата получения 31.08.55.

4. А. с. 88356 СССР. Способ производства медицинского пепсина / А.С. Цыперович (СССР). - № 410672; заявл. 8.01.50; дата получения 21.08.50.

5. А. с. 89570 СССР, Кл. 30 h 7. Способ получения искусственного желудочного сока / А.С. Цыперович (СССР). - № 430503; заявл. 26.06.50; зарегистрировано 23.10.50.

6. А. с. 97235 СССР, Кл. 91. Способ лечения прогрессирующей дистрофии мышц / Б.Н. Маньковский, Б.М. Слонимская, Д.Л. Фердман (СССР). - № 102/17-921/446905; заявл. 26.06.52; дата регистрации 27.02.54, опубл. БИ, № 2, 1954.

7. А. с. 784053 СССР, М. Кл.3 А 61 К 39/00. Способ получения специфической антисыворотки для диагностики злокачественного роста / В.П. Короткоручко, Б.А. Проценко, 
Е.И. Чернявский, А.П. Федорова, Т.П. Кудрявцева (СССР). - № 2497835/30-15; заявл. 10.06.77; зарегистр. 01.08.80. ДСП. Опубл. 19.08.81, Бюл. № 44.

8. А. с. 738585 CССР, М. Кл. 2 А 61 K 31/59. "D3”витаминная кормовая добавка, способ ее получения и устройство для осуществления способа / В.П. Вендт, Р.И. Яхимович, Г.И. Самохвалов, В.А. Богуславский (СССР). - № 2334407/30-15; заявл. 22.07.78; Опубл. 14.02.80, Бюл. № 21.

9. А. c. 1513660 СССР, МПК А 61 К 31/59. Противорахитная добавка в корм для птицы / Ю.Д. Холодова, В.П. Вендт (СССР). № 2432741/31-13; заявл. 20.12.76; зарегистр. 08.06.89. ДСП.

10. Пат. 828 Україна, МПК А61К 31/593 (2006.01). Спосіб одержання вітамін $\mathrm{D}_{3}$-білкового препарату "Відеїн" / Апуховська Л.І., Загорій В.А., Сокирко В.І., Ракша А.С., Фурсаєва Н.Ф., Василевська В.М. заявник і патентовласник Апуховська Л.І. - № 4941752/ $\mathrm{SU}$; заявл. 08.04.91; опубл. 15.12.93, Бюл. № 2.

11. А. с. 505188 СССР, МПК ${ }^{2}$ С 07 C $72 / 00$. Способ получения комплекса витамина $\mathrm{D}_{3}$ c холестерином / Р. И. Яхимович, В. А. Богуславский, В. П. Вендт (СССР). № 1923301/23-4; заявл. 22.05.73; 22.05.1973; регистр. 22.05.1973. ДСП.

12. А. c. 1074137 СССР, МПК ${ }^{3}$ C 12 N 9/04. Способ выделения глюкозооксидазы / М. Ф. Гулый, Р. Г. Дегтярь, Л. В. Гудкова, Н. В. Латишко, В. Е. Кнопок, В. К. Соколовский, А. Н. Кривчун, Г. К. Белоус, Н. И. Белов (СССР). - № 3345306/28-13; заявл. 27.07.81; зарегистр. 15.10.83. ДСП.

13. A. c. 1450372 СССР, МПК ${ }^{4} \mathrm{C} 12 \mathrm{~N} 9 / 08, \mathrm{C} 12 \mathrm{~N}$ 9/00; С 12 R 1:80. Способ получения грибной каталазы / М. Ф. Гулый, Р. Г. Дегтярь, Л. В. Гудкова, Н. В. Латишко, В. Е. Кнопок, В. К. Соколовский, А. Н. Кривчун, Г. К. Белоус (СССР). - № 4164981/31-13; заявл. 19.12.86; зарегистр. 08.09.88. ДСП.

14. Пат. 13788 Україна, МПК 5 А 61 К 33/06, A $61 \mathrm{~K}$ 33/10, A $61 \mathrm{~K} / 30$, A $61 \mathrm{~K}$ 33/32. Адаптогенний препарат та спосіб його одержання / Гулий М.Ф., Мельничук Д.О., Стогній Н.А., Шевцова Н.Ф., Тищенко Г.М., Загорій В.А., Денисов М. Д., Забарський О.Ш., Тараховський М.Л., Ципку А.Г., Денисова М.Ф.; заявники та патентовласники Ін-т біохімії ім. О. В. Палладіна НАН України, ЗАТ “Фармацевтична фірма “Дарниця”, Ін-т педіатрії, акушерства та гінекології АМН України. - № 93070757; заявл. 10.03.93; опубл. 30.06.98, Бюл. № 3.

15. A. c. 1591983 СССР, МПК 5 А 61 К 31/195, A 61 К 33/00. Способ лечения хронического алкоголизма / М.Ф. Гулый, В.Н. Синицкий, Д.А. Мельничук, Н.А. Стогний, А.Д. Ревенок, Л.С. Ушеренко, Т.Н. Печенова, Т.Т. Володина, В.В. Сушкова, Н.Ф. Шевцова (СССР). № 4365825/30-14; заявл. 18.01.88; опубл. 15.09.90, Бюл. № 34.

16. A. c. 1307814 СССР, МПК ${ }^{4}$ С 08 К 5/53, С 08 G 18/06. Полиуретановая композиция / С.В. Комиссаренко, Н.П. Карлова, Г.Н. Фомовская, А.Н. Борисевич, М.О. Лозинський, Г. А. Пхакадзе (СССР). № 3828462/23-05; заявл. 25.12.84; зарегистр. 03.01.87. ДСП.

17. A. c. 1512099 СССР, МПК ${ }^{4}$ C 07 F 9/38, А $61 \mathrm{~K}$ 31/66. Дигидрат динатриевой соли метиленбисфосфоновой кислоты, проявляющей противоопухолевую активность / С.В. Комиссаренко, Н.П. Карлова, Н.И. Шарыкина, И.Г. Кудрявцева, Л.Я. Езерская, М.О. Лозинский, А.Н. Борисевич (СССР). - № 4239930/31-04; заявл. 23.03.87; зарегистр. 01.06.89. ДСП. Раскрыто.

18. А. с. 1014556 СССР, М. Кл. 3 А 23 К 1/16. Е-витаминная кормовая добавка / Г.В. Донченко, А.А. Свищук, В.Н. Коваленко, И.В. Кузьменко, В.П. Маковецкий, В.В. Яременко, Т.Е. Сивачек, С.М. Паенок (СССР). - № 3262095/30-15; заявл. 12.03.81; опубл. 30.04.83, Бюл. № 16.

19. Пат. UA 77182. МПК (2006.01) A61P 9/10, А61К $31 / 20$. Застосування $\mathrm{N}$-ацилетаноламінів як лікарських засобів та спосіб їх використання / Гула Н.М., Маргітич В.М., Горідько Т.М., Артамонов М.В., Жуков О.Д., Клімашевський В.М., Комісаренко С.В., Жебровська Ф.І. - Заявник і патентовласник Інститут біохімії ім. О. В. Палладіна НАН України. - № 20031213067; заявл. 30.12.2003; опубл. 15.11.2006. Бюл. № 11.

20. Пат. UA 77278. МПК (2006) А61К 31/13, А61P 37/08 (2006.01). Препарат для пригнічення алергічних реакцій та неспецифічного запалення, спосібйогоодержанняіспосібйого 
використання / Гула Н.М., Комісаренко С.В., Чумак А.А., Артамонов М.В., Жуков О.Д., Мегедь О.Ф., Петрова Ю.І., Кіндрук Н.Л. Заявник і патентовласник Інститут біохімії ім. О. В. Палладіна НАН України. № 20041008401; заявл. 15.10.2004; опубл. 15.11.2006, Бюл. № 11.

21. Пат. UA 81861. МПК (2006) C07C 215/00, C07C 229/02 (2007.01). Спосіб одержання N-ацилетаноламінів / Гула Н.M., Маргітич В.М., Горідько Т.М., Артамонов М.В., Жуков О.Д., Клімашевський В.М. Заявник і патентовласник Інститут біохімії ім. О. В. Палладіна НАН України. № а200607519; заявл. 06.07.2006; опубл. 11.02.2008, Бюл. № 3 .

22. Пат. UA 85522. МПК (2009) А61К 31/164, A61P 3/10 (2008.01). N-стеароїлетаноламін як лікарський засіб в супроводжуючій протипухлинній терапії / Гула Н.М., Хмель Т.О., Клімашевський В.М., Бєрдишев А.Г., Гудзь Є.А. - Заявник i патентовласник Інститут біохімії iм. О. В. Палладіна НАН України. № a200708176; заявл. 18.07.2007; опубл. 26.01.2009, Бюл. № 2.

23. Пат. UA 85523. МПК (2009) А61К 31/164, A61P 3/10 (2008.01). Застосування $\mathrm{N}$-стеароїлетаноламіну як лікарського засобу для терапії цукрового діабету I та II типів / Гула Н.М., Косякова Г.В., Бердишев А.Г. - Заявник і патентовласник Інститут біохімії ім. О. В. Палладіна НАН України. - № а200708180; заявл. 18.07.2007; опубл. 26.01.2009, Бюл. № 2.

24. Про охорону прав на винаходи i корисні моделі: Закон України від 15 грудня 1993 р. № 3687-XII - [Электронный ресурс]. Режим доступа: http://zakon1.rada.gov.ua/laws/ show/3687-10.

25. Про охорону прав на промислові зразки : Закон України від 15 грудня 1993 р. № 3688XII [Электронный ресурс]. - Режим доступа: http://zakon1.rada.gov.ua/laws/show/3688-16.

26. Про затвердження типового положення 3 планування, обліку i калькулювання собівартості науково-дослідних та дослідноконструкторських робіт : Постанова Кабінету Міністрів України від 20 липня 1996 р. № 83 [Электронный ресурс]. Режим доступа: http://zakon4.rada.gov.ua/ laws/show/473-96-п.
27. Про спеціальний режим інвестиційної та інноваційної діяльності технологічних парків : Закон України від 4 жовтня 2001 р. № 2743-III [Электронный ресурс]. Режим доступа: http://aips-izm.principics.org.ua/ law_7.htn.

28. Про загальнодержавну комплексну програму розвитку високих технологій : Закон України від 9 квітня 2004 р. № 1676-IV [Электронный pecypc]. - Режим доступа: http://zakon1.rada. gov.ua/laws/show/1676-15.

29. Про державне регулювання діяльності у сфері трансферу технологій : Закон України від 4 вересня 2006 р. № 143-V, ст. 22 [Электронный pecypc]. - Режим доступа : http://zakon1.rada. gov.ua/laws/show/ 143-16.

30. Про наукові парки : Закон України від 25 червня 2009 р. № 1563-VI [Электронный pecypc]. - Режим доступа : http://zakon4.rada. gov.ua/laws/show/1563-17.

31. Про затвердження Національного стандарту № 4 "Оцінка майнових прав інтелектуальної власності” : Постанова Кабінету Міністрів України від 3 жовтня 2007 р. № 1185 [Электронный ресурс]. - Режим доступа: http://zakon4.rada.gov.ua/laws/show/11852007-п.].

32. Про освіту: Закон України. К.: ЮрінкомІнтер, 1996. С. 51.

33. Про наукову і науково-технічну діяльність: Закон України. К.: Юрінком-Інтер, 2010. C. 32 .

34. Статистичний щорічник України за 2012 рік. К.: Державна служба статистики України, 2013. С. 728.

35. Твисс Б. Управление научно-техническими нововведениями. Сокр. пер. с англ. Науч. ред. К.Ф. Пузыня. М.: Экономика, 1989. 271 с.

36. Хименко О. А. Інтелектуальна власність як ключовий чинник формування та реалізації стратегії інноваційного розвитку України. Матеріали міжнар. конф. «Актуальні питання охорони прав інтелектуальної власності в Україні та Європейському Союзі в контексті європейської інтеграції», м. Київ, Україна, 30 червня - 1 липня 2010 р. Київ: Фенікс, 2010. С. 300-307.

37. Вермінська О.М., Гориславець П.А. Проблеми та перспективи інвестиційноінноваційного розвитку України. 2010/ Електронний ресурс: http://ena.lp.edu.ua:8080/ bitstream/ntb/10054/1/40.pdf. 
38. Стратегія інноваційного розвитку України на 2010-2020 роки в умовах глобалізаційних викликів. Електронний ресурс: http://kno. rada.gov.ua/komosviti/control/uk/publish/ article; jsessionid=663ECDA15F78D93963CA9 A27E8EF911F?art_id $=63360 \&$ cat_id $=63355$.

39. Андрощук Г.О. Інноваційна діяльність в Україні: економічний механізм стимулювання / Інтелектуальна власність. 2000; № 12. C. 23-28.

40. Наукова та інноваційна діяльність України, 2015 рік. Державна служба статистики України. Наукова та інноваційна діяльність України. Статистичний збірник. К:, 2016.

41. Яковенко Р.В., Чернега А.М. Інноваційна діяльність в Україні: проблеми та перспективи. Аналітична доповідь центру Разумкова. Національна безпека і оборона. 2009: (7): 2-14.

42. Спосіб одержання антиалкогольного препарату "МЕДИХРОНАЛ" / Гулий М.Ф., Мельничук Д.О., Синицький В.М., Стогній Н.А., Ковтун Т.В., Сілонова Н.В., Шевцова Н.Ф., Сушкова В.В., Кас'янова Н.М., Загорій В.А., Денисов М.Д., Забарський О.Ш.; заявники та патентовласники Ін-т біохімії ім. О. В. Палладіна НАН України, ЗАТ “Фармацевтична фірма “Дарниця". № 93007398; заявл. 26.10.93; опубл. 30.08.99, Бюл. № 5.

43. Пат. 40714 А Україна, МПК (2007.01) С 01 В 15/16, А 61 K 31/327. Протипухлинний засіб / Комісаренко С.В., Шарикіна Н.I., Лозинський M.О., Карлова Н.П., Кудрявцева І.Г., К Кузьменко І.Й., Борисевич А.М., Єзерська Л.Я.; заявники та патентовласники Ін-т біохімії ім. О.В.Палладіна НАН України, Ін-т фармакології та токсикології АМН України, Ін-т органічної хімії НАН України. № 2001074659; заявл. 04.07.01; опубл. 15.08.01, Бюл. № 7.

44. Пат. 39228 Україна, МПК (2006.01) А 61 К 33/30, A $61 \mathrm{~K} 31 / 197$, A $61 \mathrm{~K} 31 / 355$, A $61 \mathrm{~K}$ 31/455, А 61 K 31/51, А 61 Р 3/02. Препарат для підвищення життєстійкості організму / Донченко Г.В., Пархоменко Ю.М., Протасова 3.С., Коваленко В.М., Даневич О.І., Кожакіна І.П., Черниш І.Ю., ФедосєєваБородіна Л.О.; заявник і патентовласник Ін-т біохімії ім. О.В. Палладіна НАН України. № 98073888; заявл. 17.07.98; опубл. 15.06.01,
Бюл. № 5. Продовж. терміну дії патенту до 17.07.23 р.; опубл. 27.02.17, Бюл. № 4.

45.Свідоцтво на знак для товарів і послуг № 37343 Україна - «КОРЕКТИН». Кл. 5 - Фармацевтичні препарати. Власник: Інститут біохімії ім. О.В.Палладіна НАН України. - № 2001053247; заявл. 29.05.2001; опубл. 16.02.2004, Бюл. №2. Свідоцтво чинне до 29.05.2011. Продовження дії свідоцтва до 29.05.2021 ; Бюл. № 7, 11.04.2011.

46. Пат.114356 Україна, МПК (2016.01) А 61 Р 7/04; А $61 \mathrm{~F}$ 13/00, А $61 \mathrm{~K}$ 38/43. Гемостатичний комбінований засіб для зупинки масивних кровотеч, у тому числі за гемофілії / Комісаренко С.В., Луговськой Е.В., Ніколаєв В.Г., Платонова, Т.М. Досенко В.С., Сахно Л.О., Снежкова Є.О., Корольова Д.С., Чернишенко Т.M., Чернишенко В.О., Горницька О.В., заявник і патентовласник Інститут біохімії ім. О.В.Палладіна НАН України. - № u201608441; заявл. 01.08.16; опубл. 10.03.17, Бюл. № 5.

47. Пат. 69283 Україна, МПК (2006.01) А 61К 39/44. Тест-система імуноферментна для кількісного визначення розчинного фібрину в плазмі крові людини / Комісаренко С.В., Луговськой Е.В., Колеснікова I.M., Співак М.Я., Гриценко П.Г., Ганова Л.О., Луговська Н.Е., Литвинова Л.М., Ляшко К.Д., Костюченко О.П., Позняк Т.А., Гоголинська Г.К., Ковтонюк Г.В., Терещенко М.I.; заявники та патентовласники Ін-т біохімії ім. О. В. Палладіна НАН України, Ін-т мікробіології і вірусології ім. Д. К. Заболотного НАН України. № u201111735; заявл. 05.10.11; опубл. 25.04.12. Бюл. № 8.

48. Пат. 69284 Україна, МПК (2011.01) А 61 К 39/44. Тест-система імуноферментна для кількісного визначення D-димеру в плазмі крові людини / Комісаренко C.В., Луговськой Е.В., Колеснікова I.M., Співак М.Я., Гриценко П.Г., Ганова Л.О., Луговська Н.Е., Литвинова Л.М., Ляшко К.Д., Костюченко О.П., Позняк Т.А., Гоголинська Г.К., Ковтонюк Г.В., Терещенко М.I.; заявники тапатентовласники Ін-т біохімії ім. О. В. Палладіна НАН України, Ін-т мікробіології і вірусології ім. Д. К. Заболотного НАН України. № u201111736; заявл. 05.10.11; опубл. 25.04.12. Бюл. № 8. 
49. Пат. 70456 Україна, МПК (2011.01) А 61 К 39/44. Тест-система імуноферментна для кількісного визначення фібриногену в плазмі крові людини / Комісаренко С.В., Луговськой Е.В., Колеснікова I.M., Співак М.Я., Гриценко П.Г., Ганова Л.О., Луговська Н.Е., Литвинова Л.М., Ляшко К.Д., Костюченко О.П., Позняк Т.А., Гоголинськач Г.К., Ковтонюк Г.В., Терещенко М.I.; заявники тапатентовласники Ін-т біохімії ім. О. В. Палладіна НАН України, Ін-т мікробіології i вірусології ім. Д.К.Заболотного НАН України. № u201114516; заявл. 07.12.11; опубл. 11.06.12. Бюл. № 11.

50. Пат. 22160 Україна, МПК (2006.01) А 61 К39/44, А 61 K 47/48, C 07 K 7/08 (2007.01), C 12 N 15/11. Штам Esherichia coli "INV" sbB - продуцент рекомбінантної неактивної субодиниці В дифтерійного токсину Corynebacterium diphtheria / Комісаренко С.В., Колибо Д.В., Романюк С.I., Кабернюк А.А., Олійник О.С., Буркальова Д.О., Редчук Т.А.; заявник i патентовласник Ін-т біохімії ім. О.В.Палладіна НАН України. - № u200604378; заявл. 19.04.06; опубл. 10.04.07, Бюл. № 4.

51. Пат. 100065 Україна, МПК (2006.01) G $01 \mathrm{~N}$ 33/49, G 01N 33/53, G 01 N 33/531. Тест-система імуноферментна для виявлення антитіл до Mycobacterium bovis / Комісаренко С.В., Колибо Д.В., Олійник О.С., Редчук Т.А., Луговська Н.Е., Сіромолот А.А., Стегній Б.Т., Герілович А.П., Завгородній А.І., Ніколаєнко І.В., Раєвська Г.С., заявник i патентовласник Інститут біохімії ім. О. В. Паладіна НАН України. - № u201413675; заявл. 19.14; опубл. 10.07.15, Бюл. № 13.

52. Пат. 118447 Україна, МПК (2016.01): А 61 B 10/00, G $01 \mathrm{~N} 33 / 49$, G $01 \mathrm{~N} 33 / 53$, G 01 $\mathrm{N}$ 33/531. Тест-система імуноферментна для виявлення антитіл до Mycobacterium tuberculosis / Комісаренко С.В., Колибо Д.В., Редчук Т.А., Олійник О.С., Галкін О.Ю., Романюк С.І., Сіромолот А.А., Луговська Н.Е., Фещенко Ю.І., Рекалова О.М., Чудіна T.O.; заявник і патентовласник Ін-т біохімії ім. О. В. Палладіна НАН України. № u201701655; заявл. 21.02.17; опубл.10.08.17, Бюл. № 15.

53. Пат. 113094 Україна, МПК (2016.01) А61К 35/14 (2015.01), A61K 35/16 (2015.01), A61P
7/00. Спосіб одержання аутологічного фібринового гелю для стимуляції регенерації кісткових і м'яких тканин i зниження інтенсивності запальних процесів / Комісаренко С.В., Луговськой Е.В., Рубленко М.В., Андрієць В.Г., Корольова Д.С., Чернишенко Т.M., Горницька О.В., Платонова T.M., Макогоненко Є.M., Чернишенко В.О.; заявник і патентовласник Ін-т біохімії ім. О. В. Палладіна НАН України. - № а201501207; заявл. 13.02.15; опубл. 12.12.16, Бюл. № 16.

54. Пат. 91805 Україна, МПК (2006.01) А $61 \mathrm{~K} 31 / 593$ A 61 K 31/355, A 61 P 3/02. Спосіб одержання вітамін D3-E білкового комплексу та отриманий цим способом лікувально-профілактичний вітамінний препарат / Спектор М.Й., Апуховська Л.І., Розенфельд Л.Г, Комісаренко С.В., Антипкін Ю.Г., Урх Йордан, Василевська В.М.; заявники та патентовласники Спектор М.Й., Апуховська Л.І., Розенфельд Л.Г, Комісаренко С.В., Антипкін Ю.Г., Урх Йордан, Василевська В.М.; передача права власності до Інституту біохімії ім. О. В. Палладіна НАН України, Рішення Держ. служби інтелект. власності України № 3799 від 10.03.2015. - № а200909887; заявл. 28.09.09; опубл. 25.08.10, Бюл. № 16.

55. Пат. 85494 Україна, МПК (2009.01): А $61 \mathrm{~K}$ 31/66 (2006.01), А 61 К 33/06 (2006.01), А $61 \mathrm{~K}$ 31/593 (2006.01), А 61 Р 19/00. Фармацевтична композиція для лікування захворювань кісткової тканини / Комісаренко С.В., Колибо Д.В., Апуховська Л.І., Безусяк А.І., Василевська В.М.; заявник і патентовласник Ін-т біохімії ім. О. В. Палладіна НАН України. - № а200802015; заявл. 18.02.08; опубл. 10.06.08, Бюл. № 11.

56. Пат. 85936 Україна, МПК (2009.01) А $61 \mathrm{~K}$ 31/593 (2006.01), A $61 \mathrm{~K} 31 / 355$, A $61 \mathrm{~K} 33 / 06$,

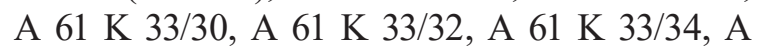
61 Р 19/10. Вітамінно-мінеральний препарат для лікування остеопорозу / Апуховська Л.І., Безусяк А.І., Василевська В.М., Волков Г.Л., Калашніков А.В., Комісаренко С.В., Колибо Д.В.; заявник і патентовласник Ін-т біохімії ім. О. В. Палладіна НАН України. № a200706950; заявл. 20.06.07; опубл. 10.03.09, Бюл. № 5.

57. Пат. 71005 Україна, МПК (2007.01) А $61 \mathrm{~K}$ 31/593. Водорозчинний препарат вітаміну $\mathrm{D}_{3}$ 
/ Апуховська Л.І., Волков Г.Л., Безусяк А.І., Василевська В.М.; заявник і патентовласник Ін-т біохімії ім. О. В. Палладіна НАН України. - № 2001117974; заявл. 22.11.01; опубл. 15.11.04, Бюл. № 11.

58. Пат. 51723 Україна, МПК (2006.01) А 61 F 9/00. Спосіб лікування катаракти / Метелицина І.П., Пархоменко Ю.М., Кузьменко І.В., Донченко Г.В., Леус М.Ф.; заявник i патентовласник Ін-т біохімії iм. О. В. Палладіна НАН України. № 99031455; заявл. 16.03.99; опубл. 16.12.02, Бюл. № 12.

59. Пат. UA 98731. МПК (2011) А61К 31/00, 31/20; A61P 5/24, 15/08, 15/10. Застосування $\mathrm{N}$-стеароїлетаноламіну як засобу в комплексній терапії та профілактиці розладів чоловічої статевої системи / Гула Н.М., Микоша О.С., Горідько Т.М., Косякова Г.В., Бердишев А.Г., Шовкун С.А., Клімашевський В.М., Комісаренко С.В. Заявник і патентовласник Інститут біохімії ім. О. В. Палладіна НАН України. № a201103251; заявл. 21.03.2011; опубл. 11.06.2012, Бюл. № 11.

60. Пат. UA 74117 U. МПК А61K 31/13 (2006.01), A61P 25/32 (2006.01), A61P 39/06 (2006.01). Засіб для профілактики та зняття алкогольної інтоксикації / Гула Н.М., Горідько Т.М., Косякова Г.В., Бердишев А.Г., Клімашевський В.М., Комісаренко С.В.Заявник і патентовласник Інститут біохімії ім. О. В. Палладіна НАН України. № u201013598; заявл. 16.11.2010; опубл. 25.10.2012, Бюл. № 20.

61. Пат. UA 75632 U. 7 МПК С 12P 19/04 (2006.01), А61 K 45/00. Засіб з антинейрамінідазною та інтерфероніндукуючою дією для профілактики та лікування грипозної інфекції / Гула Н.М., Асмолкова В.С., Рибалко С.Л., Дядюн С.Т., Старосила Д.Б., Комісаренко С.В., Чумак А.А., Бердишев А.Г. - Заявник і патентовласник Інститут біохімії ім. О. В. Палладіна НАН України. - № u201205951; заявл. 16.05.2012; опубл. 10.12.2012, Бюл. № 23.

62. Пат. UA 79010 U. МПК (2013.01) C12P 19/00 (2006/01), А61К 45\00. Застосування $\mathrm{N}$-стеароїлетаноламіну як речовини 3 активною антигрипозною дією / Гула Н.М., Асмолкова В.С., Рибалко С.Л., Дядюн С.Т.,
Старосила Д.Б., Комісаренко С.В., Чумак А.А., Бердишев А.Г. - Заявник і патентовласник Інститут біохімії ім. О.В.Палладіна НАН України. - № u201210932; заявл. 16.05.2012; опубл. 10.04.2013, Бюл. № 7.

63. Пат. UA 104650. МПК А61P 31/12 (2006/01), А61K 31/164 (2006/01) Застосування $\mathrm{N}$-стеароїлетаноламіну як речовини 3 активною антигрипозною, антивірусною, антинейрамінідазною, інтерфероніндукуючою та антигемаглютинуючою дією та засіб для профілактики та лікування грипозної інфекції / Гула Н.М., Асмолкова В.С., Рибалко С.Л., Дядюн С.Т., Старосила Д.Б., Комісаренко С.В., Чумак А.А. - Заявник і патентовласник Інститут біохімії ім. О. В. Палладіна НАН України. - № а201205950; заявл. 16.05.2012; опубл. 25.11.2013, Бюл. № 22.

64. Пат. 113605 Україна, МПК(2016.01)А61К31/00, А61К 31/20; А61P 17/02. Засіб з комплексною дією для лікування термічних опіків шкіри та лікування й профілактики опікової хвороби / Гула Н.М., Чумак А.А., Бердишев А.Г., Косякова Г.В., Горідько Т.М., Мегедь О.Ф., Онопченко О.В. Заявник і патентовласник Інститут біохімії ім. О. В. Палладіна НАН України. - № u201606900; заявл. 24.06.2016; 10.02.2017, Бюл. № 3.

65. Заявка на винахід № а201707837, МПК (2017.01) А61К 31/00, А61К 31/20; А61P 31/12. Засіб для лікування гепатиту С людини / Гула Н.М., Рибалко С.Л., Чумак А.А., Дядюн С.Т., Бердишев А.Г., Старосила Д.Б., Косякова Г.В., Горідько Т.М., Мегедь О.Ф., Асмолкова В.С., Порва Ю.І. - заявл. 26.07.2017 p.

66. Заявка на винахід № а201707836, МПК (2017.01) А61К 31/00, А61К 31/20; А61P 31/12. Засіб для профілактики та лікування інфекцій, спричинених вірусами простого герпесу 1 та 2 типів / Гула Н.М., Чумак А.А., Бердишев А.Г., Косякова Г.В, Горідько Т.М., Мегедь О.Ф., Асмолкова В.С., Порва Ю.І., Рибалко С.Л., Дядюн С.Т., Старосила Д.Б. заявл. 26.07.2017.

67. Пат. 20877 Україна, МПК (2006.01) А $61 \mathrm{~K}$ 31/51, A $61 \mathrm{~K} 31 / 255$, A $61 \mathrm{~K} 31 / 315$, A $61 \mathrm{~K}$ 31/355, А 61 Р 9/00. Препарат "Кардіовіт" для лікування та профілактики серцевосудинних захворювань / Донченко Г.В., Пархоменко Ю.М., Протасова 3.С., Кірей 3.М., 
Даневич O.I.; заявник і патентовласник Ін-т біохімії ім. О. В. Палладіна НАН України. № 96062506 ; заявл. 25.06.96; опубл. 16.04.2001, Бюл. № 3.

68. Пат. 82639 Україна, МПК (2006.01) А61К 31/355, A61K 31/10 (2008.04), A61K 31/133, A61P 39/00. Комплексний препарат для підвищення внутрішньоклітинного енергетичного обміну в організмі / Донченко Г.В., Кузьменко І.В., Кучменко О.Б., Пєтухов Д.М.; заявник i патентовласник Ін-т біохімії iм. О. В. Палладіна НАН України. № a200610264; заявл. 26.09.06; опубл. 25.04.08, Бюл. № 8.

69. Пат. 109948 Україна, МПК (2006.01) А61К $31 / 415$, A61K 31/202, A61K 33/30, A61K 33/04, A61K 33/06, A61K 31/51, А61K 31/593, A61K 31/525, A61K 31/, A61K 31/355, A61K 31/455, A61P 25/28, A61P 3/02. Засіб для лікування й профілактики та спосіб лікування й профілактики аутоімунних демієлінізаційних та нейродегенеративних захворювань центральної і периферійної нервової системи (розсіяного склерозу) / Пасічна Е.П., Донченко Г.В.; заявник i патентовласник Ін-т біохімії ім. О. В. Палладіна НАН України. № a201400618; заявл. 22.01.14; опубл. 26.10.15, Бюл. № 20.

70. Пат. 104060 Україна, МПК(2006.01) G 01 N 33/48, G 01 N 33/68. Тест-система для визначення плазміногену в плазмі крові / Гриненко Т.В., Юсова О.І., Кондратюк Г.С., Рибачук В.М.; заявник і патентовласник Ін-т біохімії ім. О. В. Палладіна НАН України.№ а201205949; заявл. 16.05.12; опубл. 25.12.13, Бюл. № 24.

71. Пат. 97067 Україна; МПК(2006.01)G 01 N33/68. Спосіб визначення активності гепаринів для субстанцій і готових лікарських форм гепаринів / Рибачук В.М., Рока-Мойя Я.М., Рясненко Л.П., Юсова О.І., Гриненко Т.В., Левчук О.В.; заявник і патентовласник Ін-т біохімії ім. О. В. Палладіна НАН України. № a201101810; заявл. 16.02.11; опубл. 26.12.11, Бюл. № 24.

72. Пат. 98552 Україна, МПК (2012.01) G 01 N 33/48 (2006.01), G 01 N 31/00. Спосіб визначення анти-ІІа-факторної активності низькомолекулярних гепаринів $\mathrm{i}$ тестсистема для визначення анти-ІІа-факторної активності низькомолекулярних гепаринів на його основі / Рибачук В.М., Рясненко Л.П., Рока-Мойя Я.М., Марченко С.М., Гриненко Т.В.; заявник і патентовласник Ін-т біохімії ім. О. В. Палладіна НАН України. № a201013600 UA; заявл. 16.11.10; опубл. 25.05.12, Бюл. № 10.

73. Пат. 61446 Україна, МПК (2011.01): G 01 N 33/48 (2006.01), G 01 N 31/00. Тестсистема для визначення анти-ІІа-факторної активності низькомолекулярних гепаринів / Рибачук В.М., Рясненко Л.П., РокаМойя Я.М., Марченко С.М., Гриненко Т.В.; заявник і патентовласник Ін-т біохімії ім. О. В. Палладіна НАН України. - № u201013601 UA; заявл. 16.11.10; опубл. 25.07.11, Бюл. № 14.

74. Пат. 86279 Україна, МПК (2013.01) А 61 В 10/00. Спосіб прогнозування післяопераційних тромботичних ускладнень / Луговськой Е.В., Колеснікова I.M., Платонова Т.М., Луговська Н.Е., Литвинова Л.М., Костюченко О.П., Рубленко А.М., Фіщенко В.О. Чернишенко Т.М., Горницька О.В., Комісаренко С.В.; заявник і патентовласник Ін-т біохімії ім. О. В. Палладіна НАН України. - № u201307461; заявл. 12.06.13; опубл. 25.12.13, Бюл. № 24.

75. Пат. 86175 Україна, МПК (2011.01): G $01 \mathrm{~N}$ 33/18, G 01 N 33/24, G 01 N 21/76, G 01 N 33/569, G 01 N 35/00. Спосіб експресного визначення рівня інтегральної забрудненості, вмісту токсичних органічних сполук та важких металів в об'єктах довкілля / Грузина Т.Г., Рєзніченко Л.С., Назаренко В.І., Мельник В.Г., Дибкова С.М., Ульберг 3.P.; заявники та патентовласники Інститут біохімії ім. О. В. Палладіна НАН України, Інститут біоколоїдної хімії ім. Ф. Д. Овчаренка НАН України, Інститут електродинаміки НАН України. - № а201108519; заявл. 07.07.11; опубл. 25.12.13, Бюл. № 24.

76. Пат. 90605 Україна, МПК (2014.01) G $01 \mathrm{~N}$ 33/18 (2006.01), G 01 N 33/24 (2006.01), G 01 N 21/76 (2006.01), G 01 N 33/569 (2006.01), G 01 N $35 / 00$. Пристрій для експресного визначення рівня інтегральної забрудненості, вмісту токсичних органічних сполук та важких металів в об'єктах довкілля / Грузина Т.Г., Рєзніченко Л.С., Назаренко В.І., Мельник В.Г., Дибкова С.М., Ульберг 3.Р.; заявники та патентовласники Інститут біохімії ім. 
О. В. Палладіна НАН України, Інститут біоколоїдної хімії ім. Ф. Д. Овчаренка НАН України, Інститут електродинаміки НАН України. - № u201311195; заявл. 07.07.11; опубл. 10.06.14, Бюл. № 11.

77. Електронний pecypc: https://ua.censor.net. ua/news/444233/ukrayina_polipshyla_sviyi_ pokaznyk_u_globalnomu_innovatsiyinomu_ indeksi.

78. Стратегія інноваційного розвитку України на 2010-2020 роки в умовах глобалізаційних викликів. Проект. Електронний ресурс. http://kno.rada.gov.ua/komosviti/control/uk/ publish/article;jsessionid=663ECDA15F78D 9 3963CA9A27E8EF911F?art_id=63360\&cat_ $\mathrm{id}=63355$.
79. Електронний pecypc: https://ua.censor.net. ua/news/444233/ukrayina_polipshyla_sviyi_ pokaznyk_u_globalnomu_innovatsiyinomu_ indeksi .

80. МОН розробив пакет законів для розвитку інновацій, що передбачає субсидії для високотехнологічних виробництв. http:// mon.gov.ua/usi-novivni/novini/2017/06/09/ mon-rozrobiv-paket-zakoniv-dlya-rozvitkuinnovaczij/ 